د · شيماء فتحي عبدالصادق عـ

\title{
غزائبية العنوان
}

\section{في مسرح السيد حافظ}

د. • شيماء فتحي عبدالصادق (")

مقدمةة :

العنوان هو الاسم الذى يمثل العمل ويعبر عنه ، وهو العلامـــة البــصرية

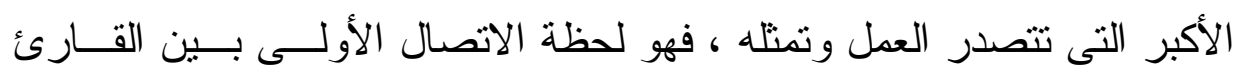

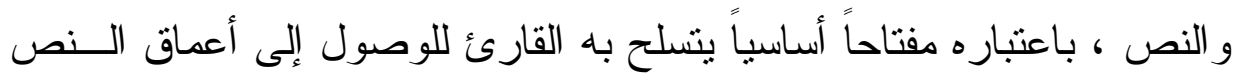

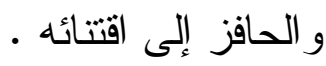
فقد حظى العنوان بأهمية كبيرة فى مسر ح السيد حافظ، حيــث لا مــدخل للنص إلا من عنو انه، و لا فهم للعنوان إلا من خلال النص الذى بنتمى إليـــهـ ،

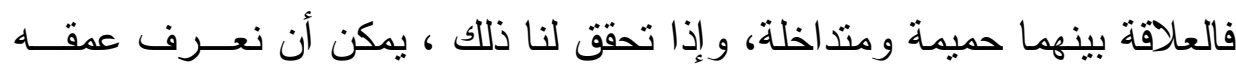
الالالى ونلامس حقيقته الجمالية ، فهو بمثابة القمة من القاعدة أو الر أس مسن وكن

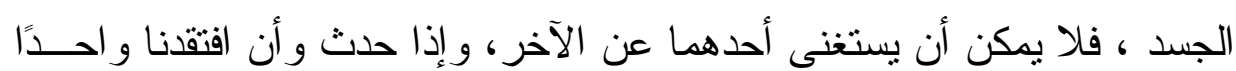
منهما صسار العمل ناقص الهوية . فالسيد حافظ يمتلك قدرة شديدة على استتطاق العناوين المميزة و الغربيـــة، ويظهر هذا بوضوح فى أسماء نصوصه المسرحية ، فالعنوان فى مسرحه يرسم بلغته المكثفة تصور اً فى ذهن القارئ ،لما بصدد قر اعته فى النص المعنون، أو يثير أسئلة فى ذهن القارئ تبحث عن إجاباتها فى ذلك النص ، ومن هنا يبــرز مدى ارتباط العنوان بالنص فيكون العنوان عتبة مهمة ترشد القارئ فى قر اعته 


\section{غ غر ائبية العنوان}

لكن يظل العنوان علامة فارقة لدى السيد حافظ ، وكما يقولون: إن العنوان

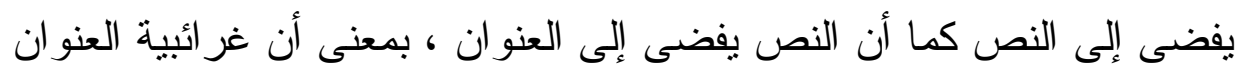

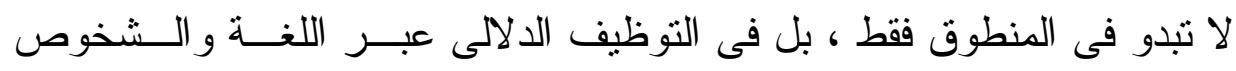

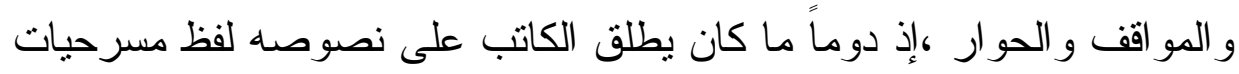

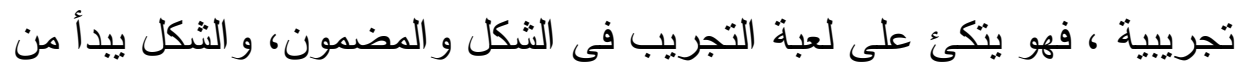

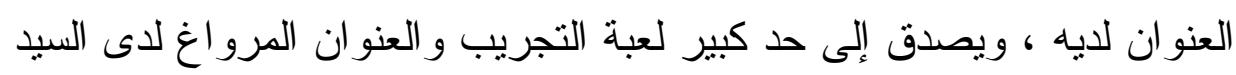
حافظ بشكل ملموس فى العديد من كتاباته . العنوان كمصطلح لغوي:

فى معجم المصطلحات الأدبية المعاصرة بعرف العنوان من خلال ارتباطه

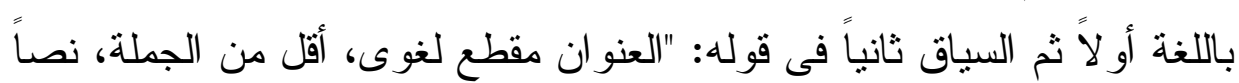

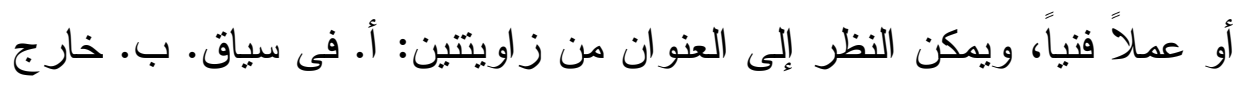

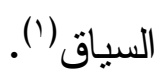

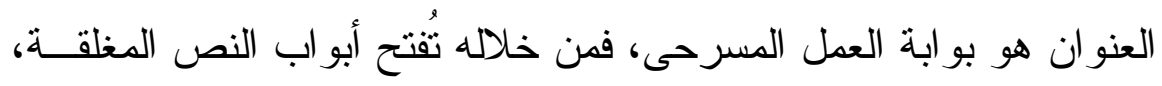

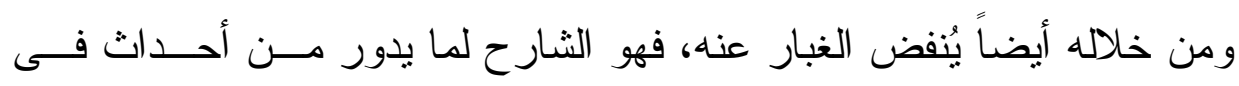

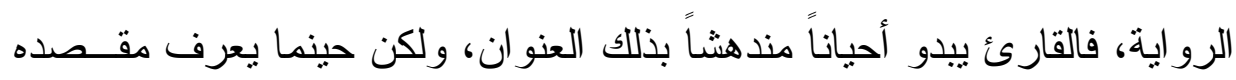

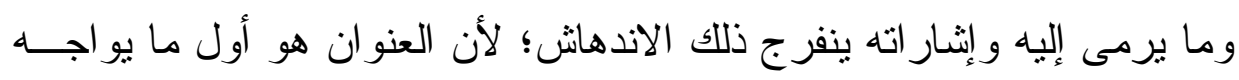

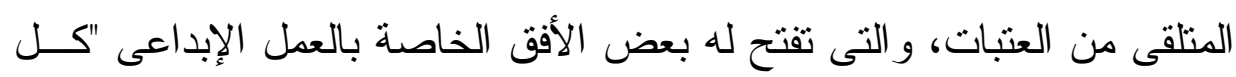

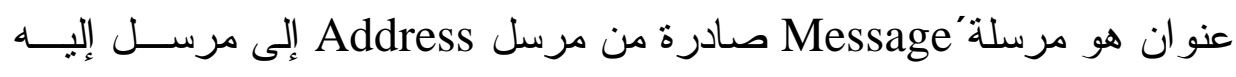
Addressee

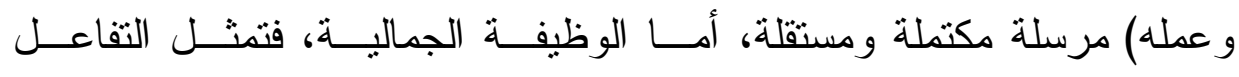

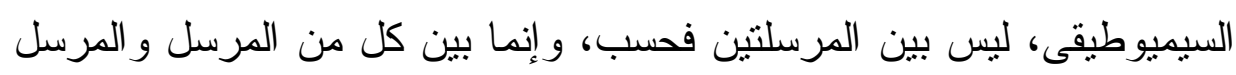

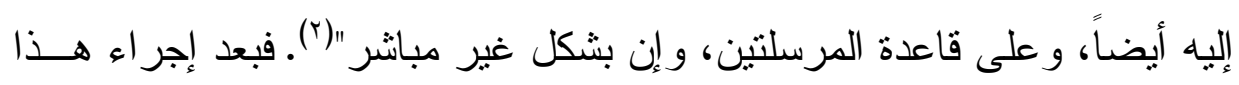

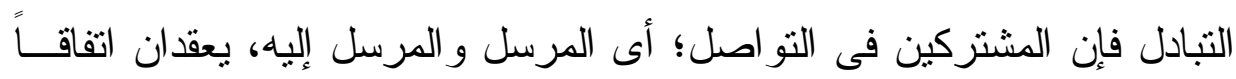




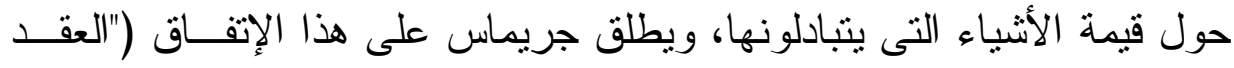
القولى" وهو يفترض فى التحول السردى عملية معرفية يتم عقبها اقتر اح وقبول

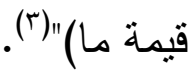

ولذلك نجد الكاتب يحاول قدر المستطاع أن يجعل العنوان مــدخلاً لفهــ

النص.

"إن المرسل يتأول عمله فيتعرف منه على مقاصده، وعلى ضـــوء هــــه

المقاصد يضع عنو اناً لهذا العمل، بمعنى أن العنوان من جهة المرسل، هو ناتج تفاعل علاماتي بين المرسل و العمل(ء).فالعنو ان نفسه بمنل علامة أو إثـــارة إلى ما فيه من تقاعلات، لذللك فالكثثر من الأدباء يضع العنوان بعد الانتهاء من

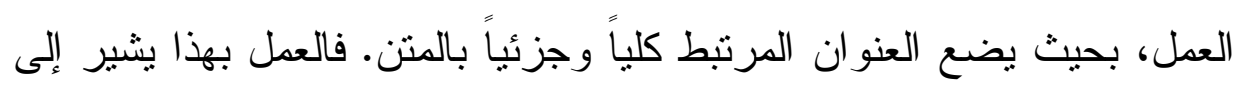

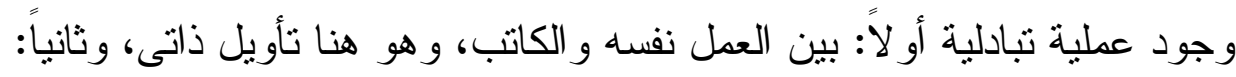
بين العمل و المتلقى لهذا العمل حتى التفاعل بين المؤلف و العمل نفسه، الأمــر الذى يقوده إلى حسن اختيار عنوان له، ومن هنا يأتى دور المتلقى لذلك العمل محاو لاً فهمه وتفسيره وفق العنوان، من خلال فهم إثار اته و الهدف منه.

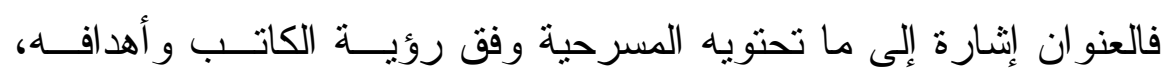

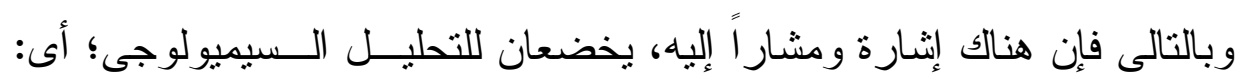

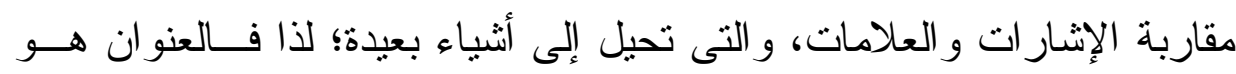

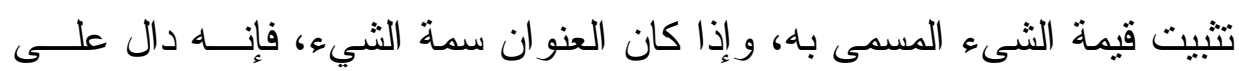

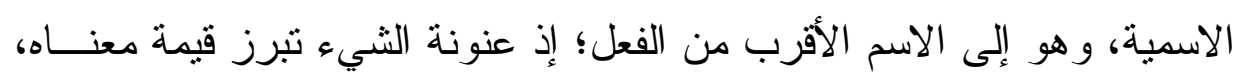

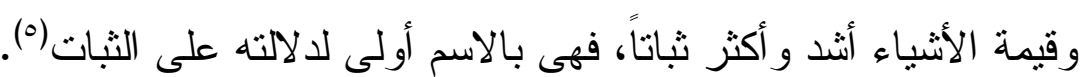
ويشير جميل حمداوى إلى العتبات قائلاً: "يتضمن فضاء النص من عنوان ومقدمة وعناوين فرعية داخلية للفصول، بالإضـافة إلى الملاحظات التى يمكـن

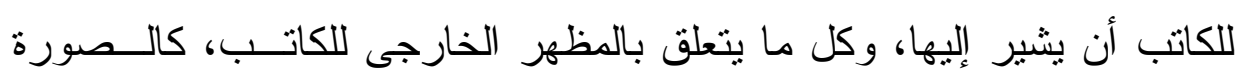
المصاحبة للغلاف أو كلمة الناشر على ظهر الغلاف أو مقطع من الحكى"(؟). 
لم يول النقاد و الدارسون اهتماماً لعتبات النص إلا فى الدراسات السيميائية المعاصرة، "حيث اهتمت السيميائية بكل ما يحيط بالنص ... بعدما تبين أنها من

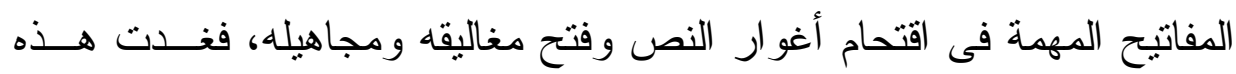

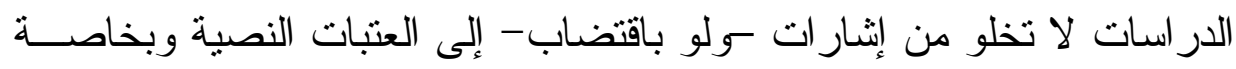

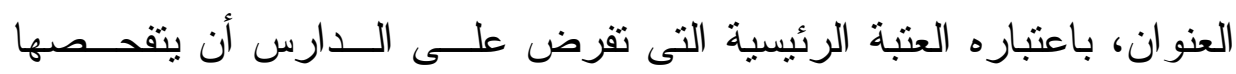

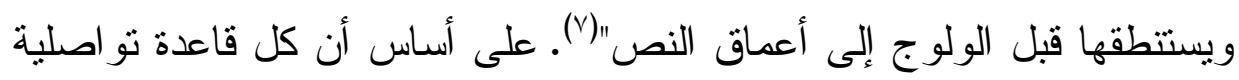

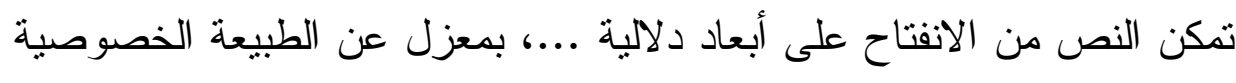

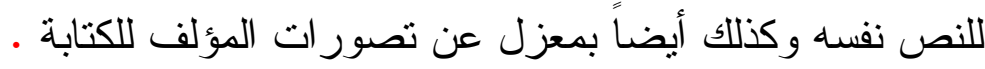

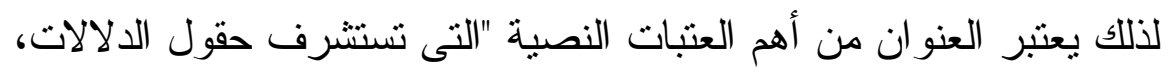
وتطل على ظله المعانى وتألق العبارات، وتفسح المجال نحو آفاق لا متتاهية،

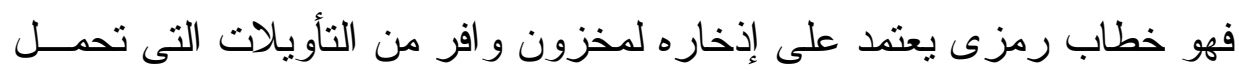

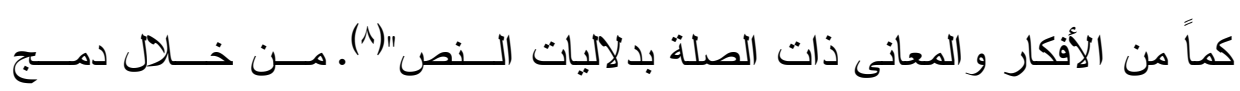

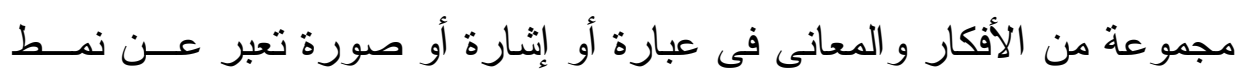

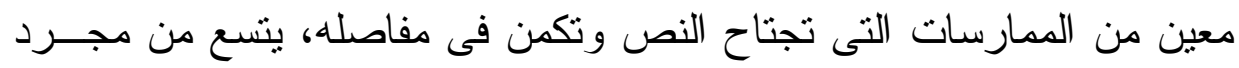

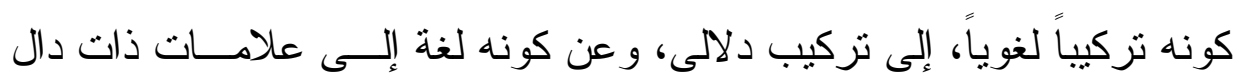
ومدلول.

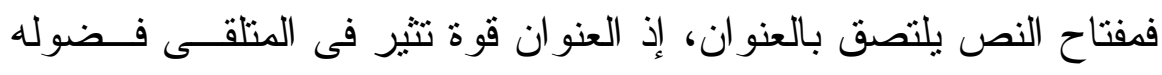

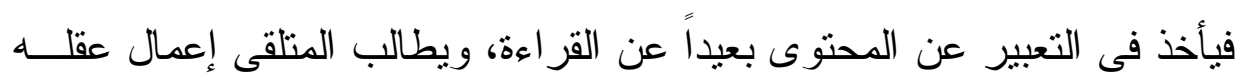

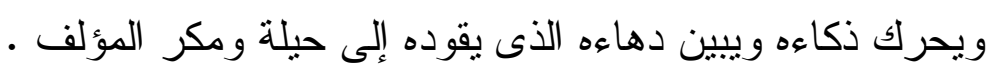

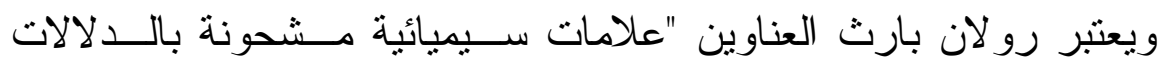

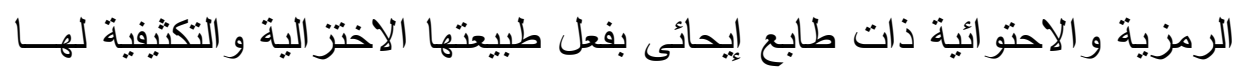

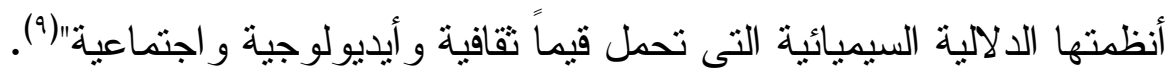


فالعنوان -إذن - "نظام سيميائى ذو أبعاد دلالية و رمزية و أيقونية، وهــو كالنص قد يصغر القارئ عن الصعود إليه، وقد يتعالى هو عـن النـزول لأى

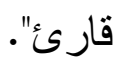

\section{وظيفة العنوان:}

للعنوان وظائف كثيرة، فتحديدها يساهم في فهر النص وتقسيره، وخاصة

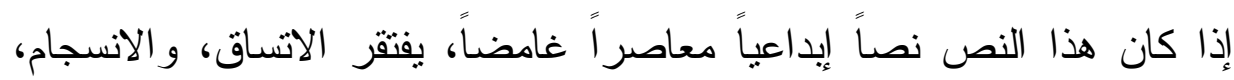
و الوصل المنطقي، و التر ابط.

ويرى جون كوهن أن أهم وظائف العنوان الأساسية "الإسناد و الوصل، كما يعتبر العنوان من أهم العناصر التي يتم بها تحقيق الربط المنطقي، وبالتالي، فالنص إذا كان بأفكاره المبعثرة مسنداً، فإن العنوان سيكون بطبيعة الحال مسنداً إليه، ويعني هذا أن العنوان هو الموضوع العام، بينما الخطاب النصي يشكل أجز اء العنوان، حيث إن العنوان في النص يرد باعتباره فكرة عامة أو دلالة محورية أو بمثابة نص كلي"('). فالنص لا بد وأن يعنون، فهي سمة من سمات

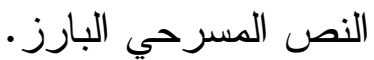

فالعنوان يحقق وظيفة الاتساق والانسجام على مستوى بناء النص أو الخطاب، ويعد كذلك من أهم العناصر التي يتم بها تحقيق الوحدة العضوية و الموضوعية والثعورية، فالعنونة هي أولى المراحل التي يقف لديها الباحث لتأملها و واستتطاقها، قصد اكتشاف بنيتها وتر اكيبها و ومنطوقاتها الدلالية ومقاصدها التداولية، فالعناوين عبارة عن علامات سيميوطيقية تقوم بوظيفة الاحتو اء لملول النص، كما تؤدي وظيفة تتاصية، ولا سيما إذا كان العنوان يحيل على نص خارجي، يتتاسل معه ويتلاقح شكلاً وفكراً. فالعنو ان هو" الذي يسمي النصوص و الخطابات الإبداعية، ويعينها، ويخلق أجو اهها النصية والتتاصية، وذللك عبر سياقها الداخلي و الخارجي، علاوة على 


\section{غر ائبية العنوان}

استيعابه للأسئلة الإثكالية التي تطرحها هذه النصوص و الخطابات، وذلك عبر عناوينها الوسيطة و البؤرية"(').

و عليه "فللعنو ان عدة وظائف سيميائية، يمكن حصر ها في وظيفة التيفة التعيين

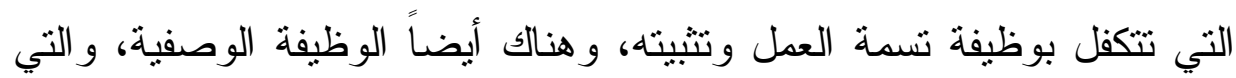
تعني أن العنوان يتحدث عن النص وصفاً وشرحاً وتفسير اً وتأويلاً وتوضيحاً.

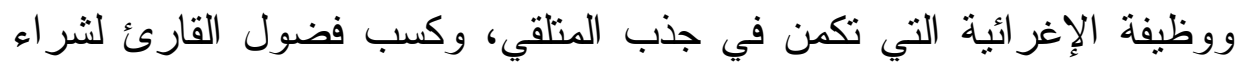

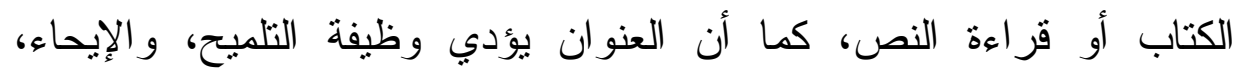

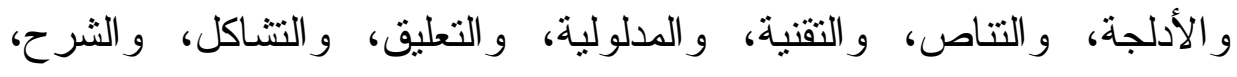

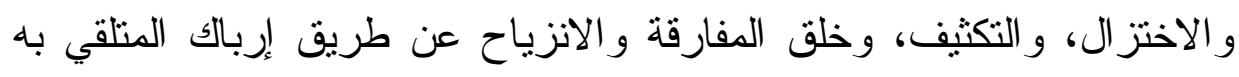

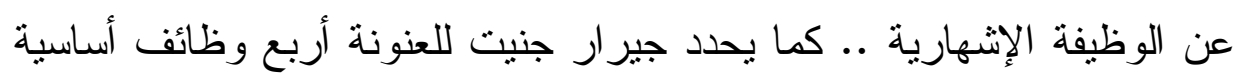

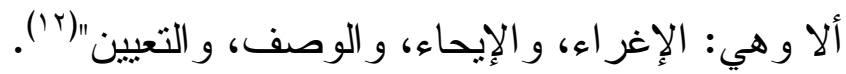

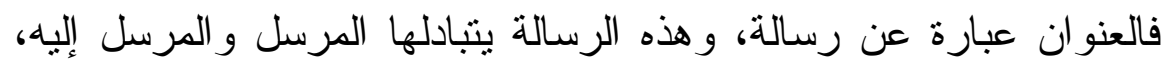

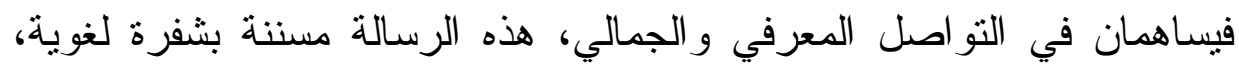
يفكها المستقبل.

لذلك وظيفة العنوان هي أنه "ينطوى علــى بعـــ الوظــائف الظـــاهرة

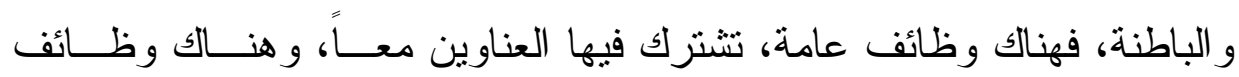

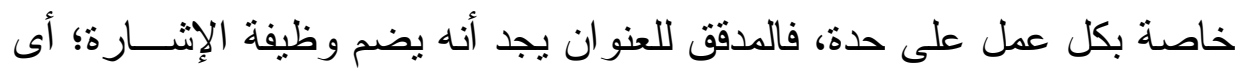

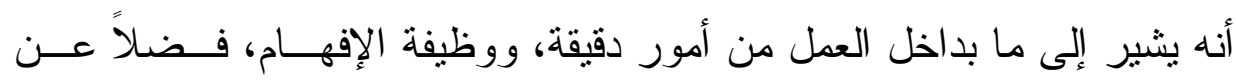

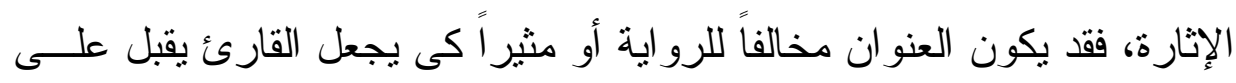

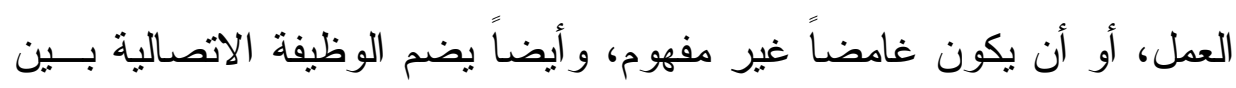

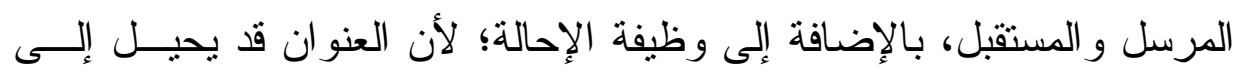
النص كما أن النص يحيل إلى العنوان"(rا'). 


\section{د · شيماء فتحي عبدالصادق}

وبالتالى فإن الكاتب يبحث فى كيفية إيصال مفهومه إلى المتلقى من خلا

وظائفه التى تجعل المنلقى فى سؤال دائم عن الهدف من العنوان ، و يبحث المتلقى إذاً عن شفراته، لسبر غوره و استكناه معالمه، فالعنوان ينجح فى إقامة اتصال نوعى بين المرسل و المتلقى ، فالمتلقى حينما يقر أ عنوان النص بطر أ له عدة تأويلات ، ومن ثم يتوجه إلى النص وفى ذهنه قد علقت هذه التأويلات التى قد تتفى أو تتعذر عند قر اعته لنص هذا العنوان . أقسام العنوان: - (n)

هناك أنواع عدة من العناين: العنوان الخارجي الذي يتربع فوق صفحة الغلاف الأمامي للكتاب أو العمل أو المؤلف، وبجانبه العنوان الأيقوني البصري لهري لهوب في شكل لوحة تشكيلية أو صورة مشهدية أو أيقونة سيميائية قائمة على الترميز و التدليل، ويؤدي العنوان الخارجي إلى جانب العنوان البصري "عدة وظائف سيميائية، كوظيفة التعيين و التسمية، ووظيفة الوصف و الثرح، ووظيفة الإغر اء

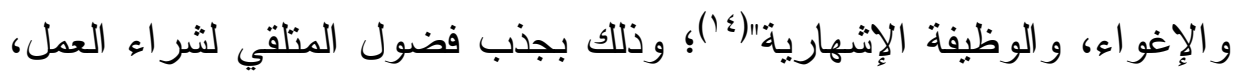
و الإقبال عليه قر اعة و إنتاجاً.

ويوجد تحت العنوان الغلافي الخارجي ما بسمى بالعنوان التعييني أو التجنيسي، والذي يحدد جنس العمل الأدبي بمجموعة من التوصيفات النقدية التي تتدرج ضمن نظرية الأدب، منل: شعر، رواية، مسرحية، قصة قصيرة، ..إلخ. وهنالك عناوين أخرى، كالعنوان الأساس الذي يكون على رأس قصيدة شعرية أو فصل من الرواية أو مشهـ مسرحي أو قسم من الدراسة

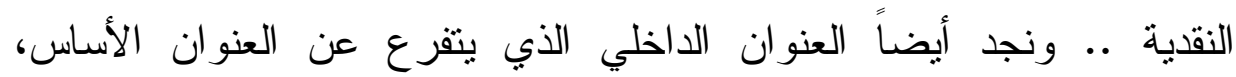
و العنوان المقطعي الذي يميز بين المقطع و الفقرات و المتو اليات النصية، كما نجد كذللك ضمن النصوص الثعرية أو النصوص الثذرية ما يسمى بالعنوان الثذري، و أيضاً هنالك عناوين أخرى في مجالات الأبحاث و الار اسات الوصفية كعناوين الأقسام و الفصول و المباحث، إلى جانب العنوان الفهرسي المرتبط 


\section{غر ائبية العنوان}

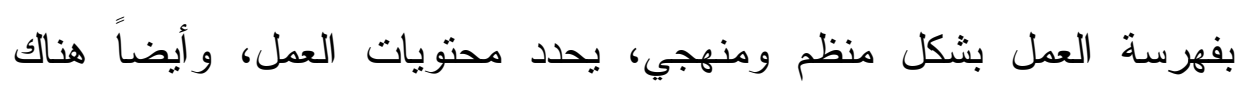

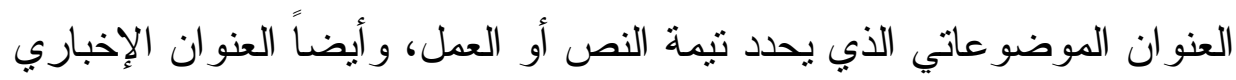

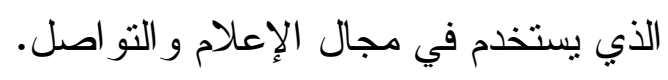
أهمية الدر اسة:

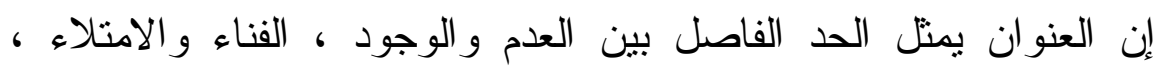

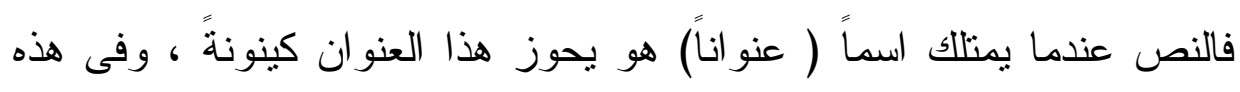

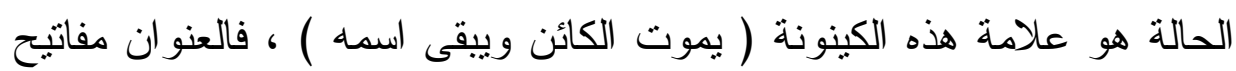

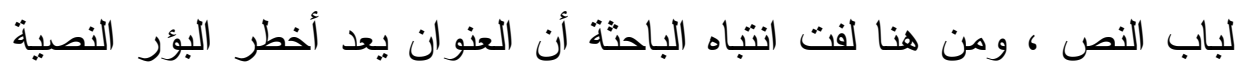

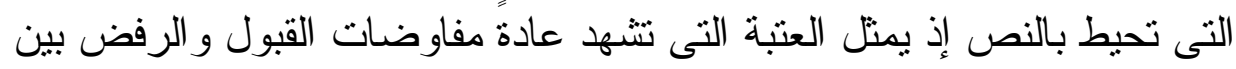

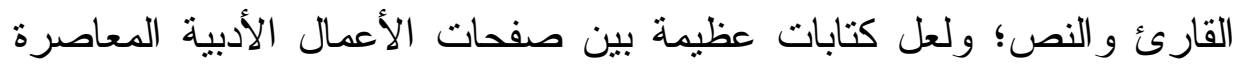

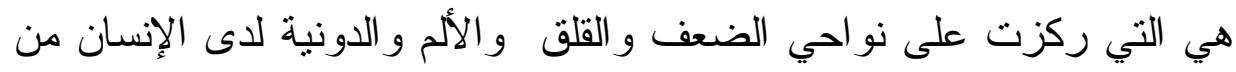

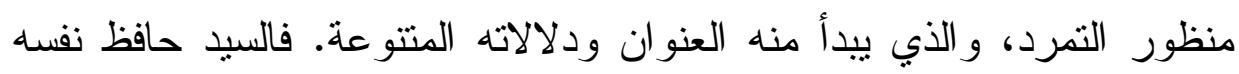
جمع التمرد وكثفه من خلال عناوين النص المسرحي وملامح البطل لديه...

$$
\text { يبدو مسرح السيد حافظ أكثر غر ابة. }
$$

فالثخصيات قد تكون رموزاً وقد تكون أصواتاً وقد تكون حيو انات بشرية،

$$
\text { وتبدأ الغربة لديه في أسماء مسرحياته: }
$$

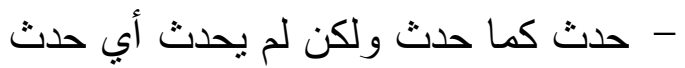

$$
\begin{aligned}
& \text { - الطبول الخرساء في الأودية الزرقاء }
\end{aligned}
$$

- قرية المرفوض في مدينة الرفض ترفض رفض الأشياء

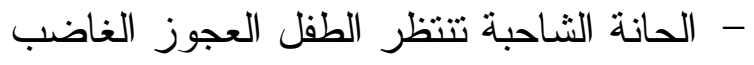

$$
\begin{aligned}
& \text { - هم كما هم ولكن ليس هم الزعاليك } \\
& \text { - كبرياء التفاهة في بلاد اللامعنى هم لهن }
\end{aligned}
$$

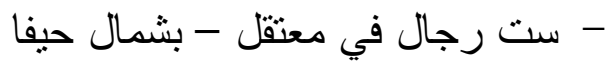


دـ ـ شيماء فتحي عبدالصادق عـ

$$
\text { - حكاية مدينة الزعفر ان حبيتي أميرة السينما }
$$

هذه الأسماء هل لها معنى؟ أكيد لها معنى، ولكن ييقى بعد هذا، هل يصل

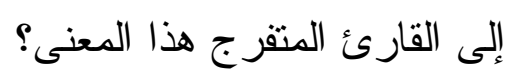

فلو تأملنا جيداً أسماء مسرحياته فماذا سنجد؟ سنجد أنها تتركب من

مجموعة من المفردات التالية وهى :( الكبرياء - التفاهة - اللامعنى الخرساء - الرفض - الثاحبة - تتنظر - الطفل العجوز - الغاضب معتقل) هذه الكلمات تختصر رؤية المؤلف للعالم، وهي رؤية مأساوية، كما تختصر شعوره القائم على الغضب و على رفض التفاهة و اللامعنى..

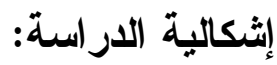

العنوان يفتح شهية القارئ للقر اءة أكثر من خلال نز اكم علامات الاستفهام فى ذهنه، و التى بالطبع سببها الأول هو العنوان فيضطر إلى دخول عالم النص بحثًا عن إجابات لتلك التساؤ لات بغية إسقاطها على العنوان .

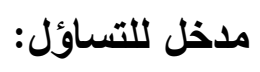

الكاتب في المسرح ما هو دوره؟ هل يحاكي العالم من خلال غرائيية

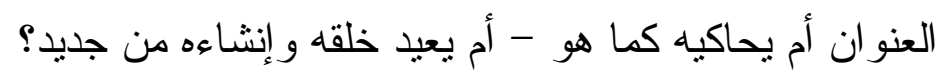

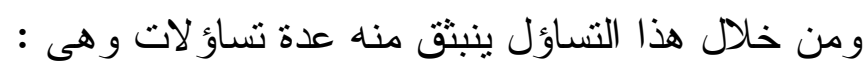
- لماذا اختار هذا الكاتب العنوان ؟ - ما مدى علاقة العنوان بالنص ؟

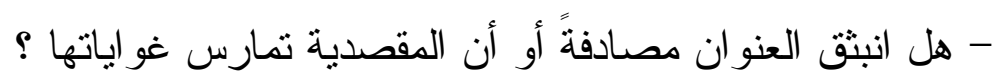
- هل هناك شروط معينة لصياغة بنية وتر اكيب العنوان ؟ هل - ما نوع الدلالات التى يحملها العنو ان ؟ وكيف تتم عملية تأويلة ؟ 
فالكاتب إذا أر اد أن يحاكي العالم، فأب شيء يمكن أن يحاكيه؟ هل يحاكي المخلوقات أم مبدأ الخلق؟ هل يستتسخ الزمن و المكان و الناس و العلاقات

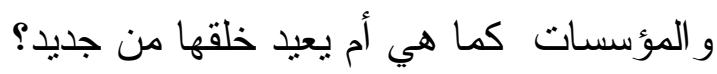

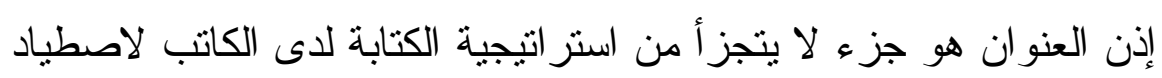

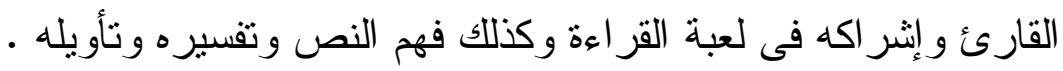
منهج الار اسنة: العنوان هو المفتاح الضروري لسبر أغوار النص، والتعمق في شعابه،

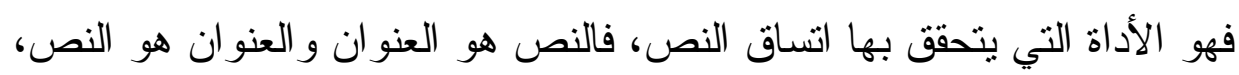

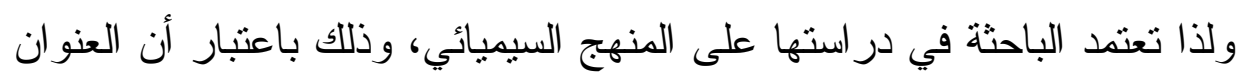

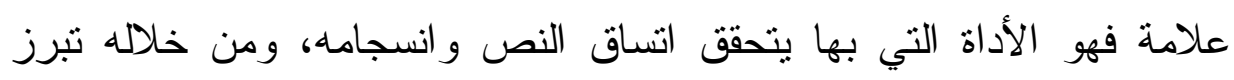

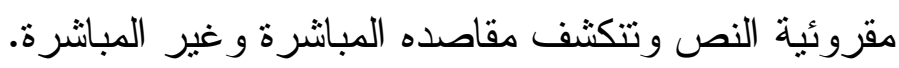

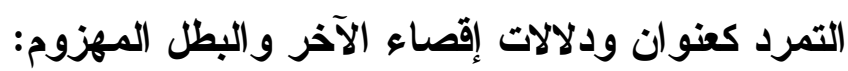

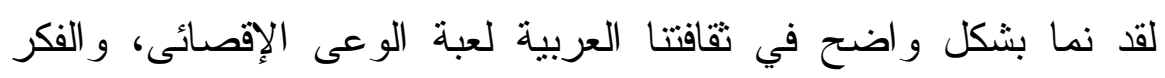

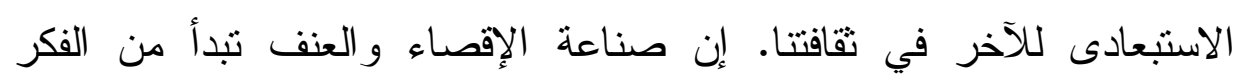
النظري غالباً لتنتقل بعد ذلك إلى ممارسة له في الو اقع.

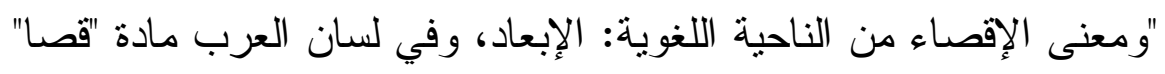

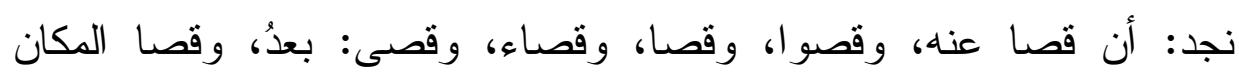

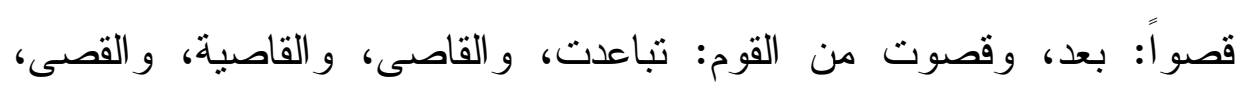

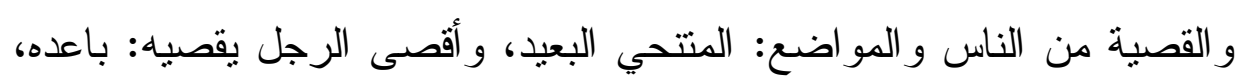

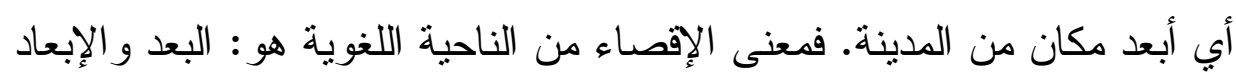
و الاستبعاد. ومفهوم الإقصاء من الناحية الاصطلاحية لا يبعد في تعريفه عن الدلالة

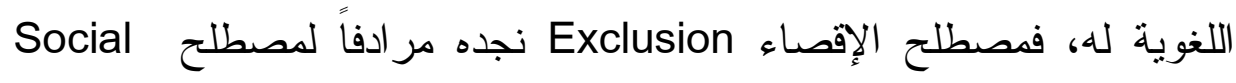




\section{د ـ شيماء فتحي عبدالصادق}

Closure

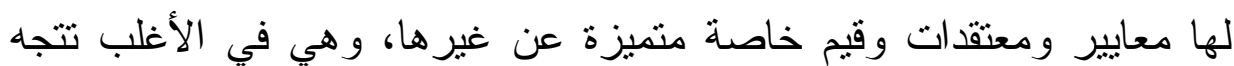

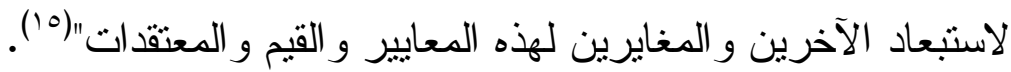
و على ذلك فالإقصاء من الناحية الاصطلاحية يعنى "قوة جماعة واحدة

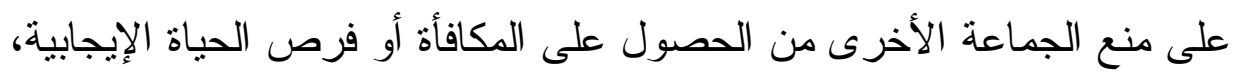

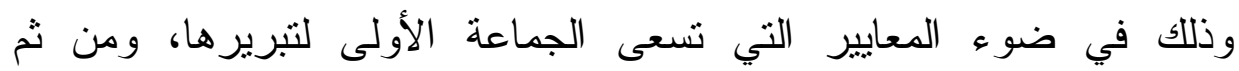
فالإقصاء هو حشد القوة لاستبعاد أو حرمان الآخرين من الامتيازات

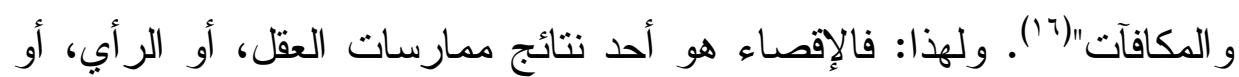

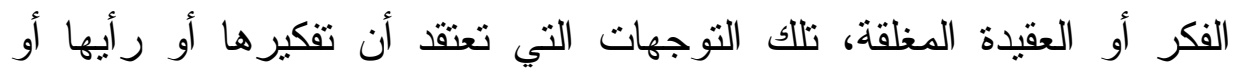
معتقدها هو وحده الذى يملك الصدق المطلق، و الحق المطلق، وأن ما عداها على ضلال مطلق، وخطأ مطلق، هنا فقط يتحقق مفهوم الإقصاء.

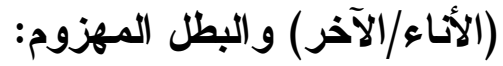

تبرز هذه الثنائية في ضوء مشروع بطل ناقص مهزوم، حيث تتقم الذات لديه إلى ذات و اقعية تجسدها الأناء الغافلة، وذات مثالية يمنلاها الأناء التي يحلم

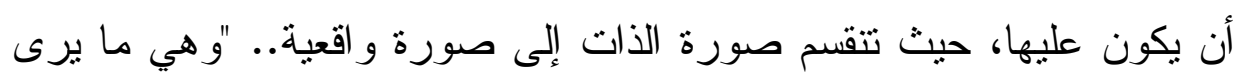

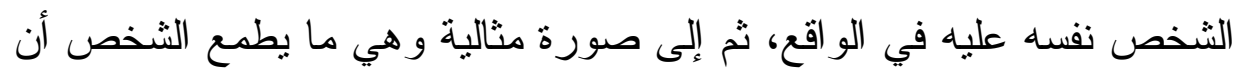

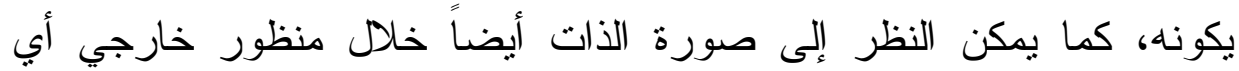

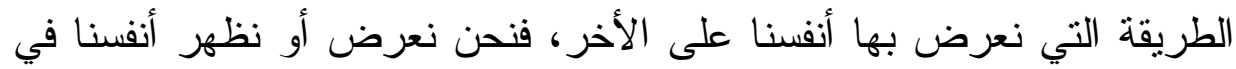

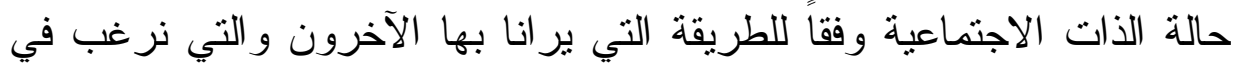

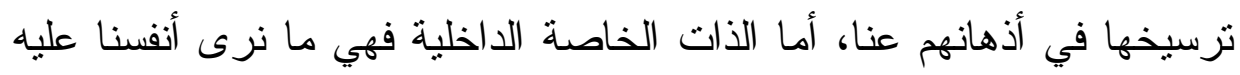

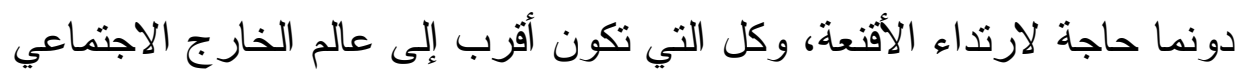

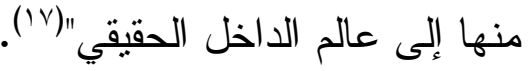
ومن لعبة الإقصاء يدخل السيد حافظ لعمق الفكرة وتجلياتها الدرامية و الحياتية، حيث التمرد عند السيد حافظ هو شخص .. لا يخطب و لا يحمل 
سلاحاً لا يقتل و لا يسفك الدماء .. يستخدم سلاح الكلمة و هي أثند فتكاً من

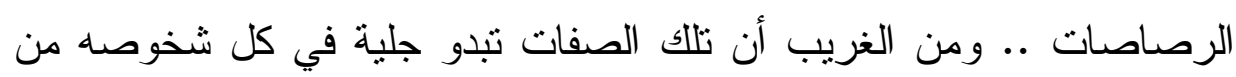

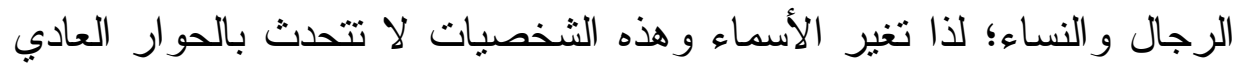

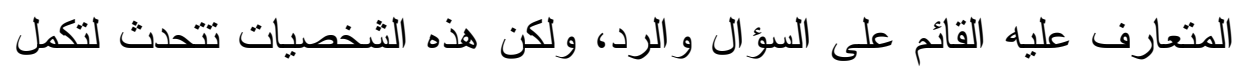

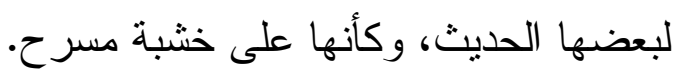
فإذا كان "حنفي" في (حبيتي أنا مسافر) "يعبر عن تمرده قائلاً: "لأجلاك

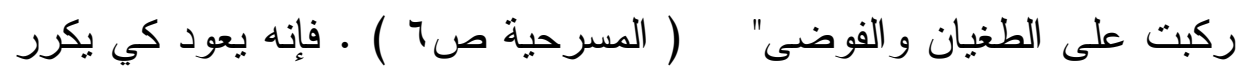

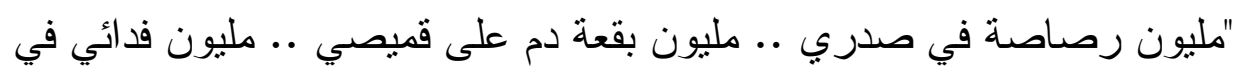

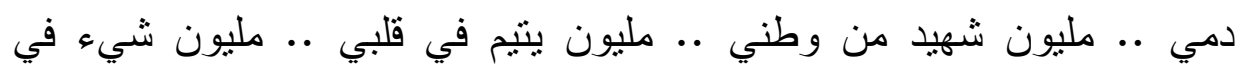

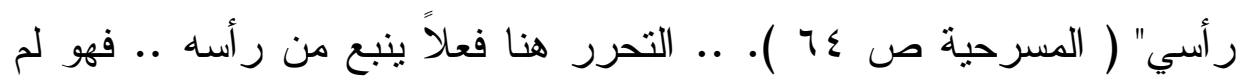

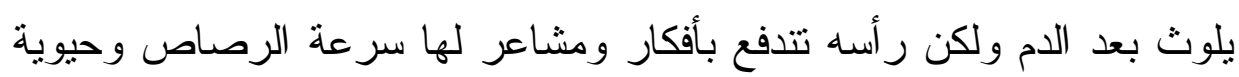

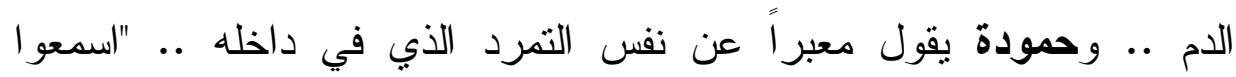

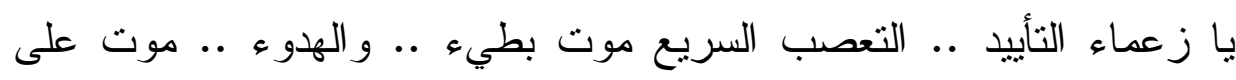
مهل .. تذكروا الورود لا تذبل في الروح" (المسرحية ص 9 ـ 1 ( ) ).

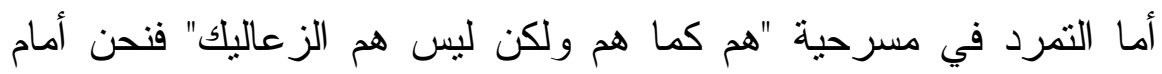

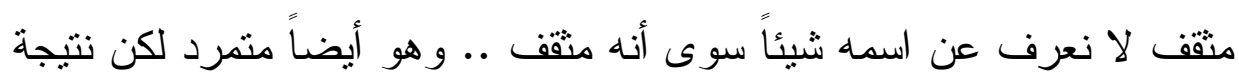

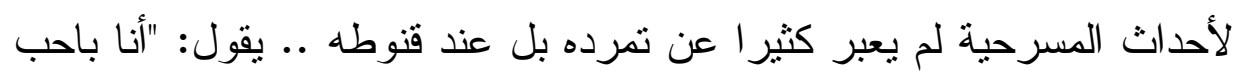

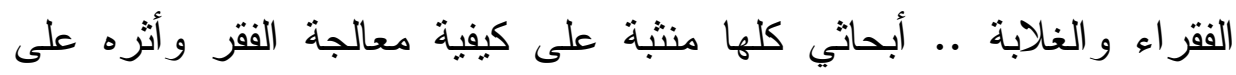

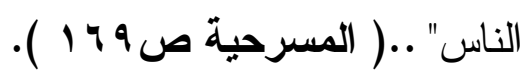
أما في مسرحية "الطبول الخرساء في الأودية الزرقاء" فنحن أمام إنسان

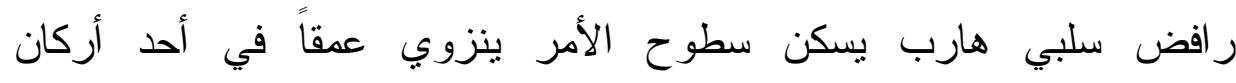
الخصوبة .. لكنه يرغب أن تكون حياته و اضحة كالثمس .. هذا البطل البطل أبضاً

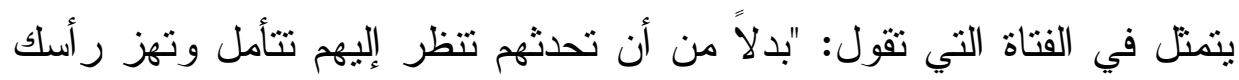




\section{د · شيماء فتحي عبدالصادق}

وتبكي وضحكاً ونسير"، وبالرغم من أن الفتى يعلن لفتاته أنه جاء من أجل الثورة ويكرر هذه العبارة.

ولكنها بشكل أو بآخر ثورة سلبية أو نوع من التمرد الداخلي فهو سيقود الصمت الملون بالظلم في النفوس البشرية، و أنه سوف يقود الانسحاق للطاغية الإمبريالية .. و الفتاة تدرك منذ البداية هذه السلبية لدى حبيبها .. فهي تسخر منه وتطلب أن ينادي على الصمت الذي سيقوده وهي تعرف أن لا أحد يجيب .. وتصرخ أن كل ما يقول هو .. شعار ات لا أكثر، وهنا نحن أمام أفضل نماذج التمرد الذين يهتفون من جوفهم أن الثورة ستقود الصمت المطعون أو أن الثورة سوف تجيء وكلما طلبناها.

و هذا الفتى لا يكف طيلة المسرحية عن الحديث حول الثورة التي لا يعي منها سوى اسمها "و إذا كان التمرد عند البطل قائمًا على التحدي للحاكم كما يعلن الفتى أكثر من مرة .. فان الحاكم فيما بعد يتحدى ويتحول إلى إنسان ظالم .. و الفتى يرى من الحاكم إنسان قاتل ... وتتمثل السلبية الثورية في مفهوم الفتى عندما يقرر بأن الثورة ما هي إلا راية وقصيدة بدلا من أن تصبح الثورة

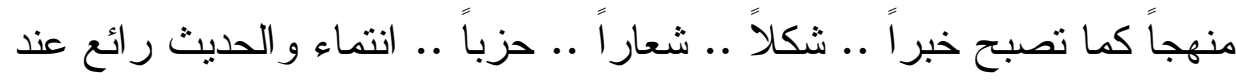
الفتى عندما يقول أنه يجب أن تصنع الثورة من حروف وتتحول إلى مصانع وحقول وأن تتحول إلى امرأة و إنسان .. وأن تصبح الحروف هزيلة تعشق هن الضباب وتتكل معنى آخر غير الأصل وتصبح العناوين ستار اً كائناً(^). . وهذه الأشياء كلها كما جاء على لسان أحد أثخاص المسرحية هي هروب في الألفاظ و الغموض، فما أحلى أن يصنع الفتى عبار ات .. أنه يهتق فقط ... ومن الواضح أن الأبطال هنا يظلمون التركيب الثوري المتعارف عليه، فالفتاة المعروفة بنضجها، تقول أن الفتى يكرر عبار ات تملؤها الثعارات . . هذه الفتاة ثقول أن الثورة أصبحث صورة شعرية، وحلم الطهارة هي صورة وحلم فقط، فالمتمرد هنا يرسم ثورته في الكتابات و الهتافات لكنه لا بصنع 
الثورة .. ربما لأن المثقفين لا يهتمون دائماً سوى بحيثيات الثورة؛ لكنهم

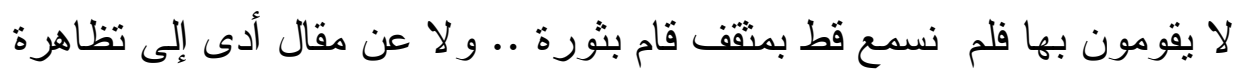

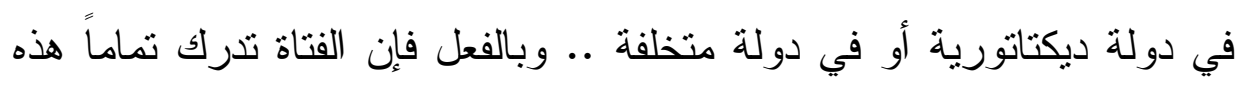
السلبية لاى الفتى المثقف وتحدثه من جديد ساخرة في نهاية المسرحية قائلة ..

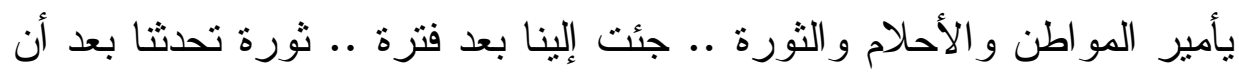

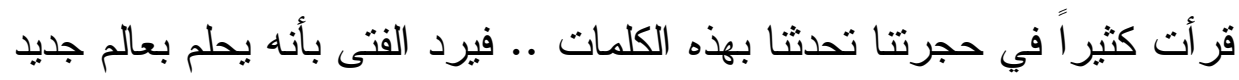

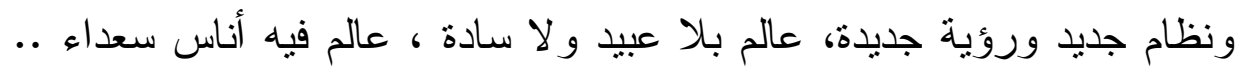

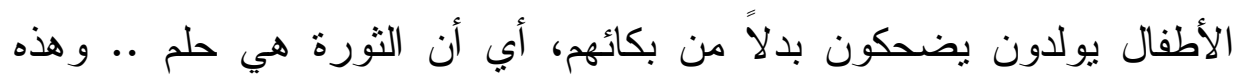

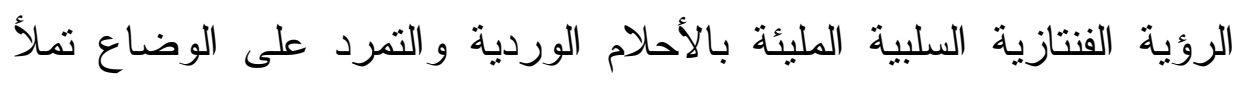
شخصيات مسرح السيد حافظ، وتبدو منذ العنوان جلية.

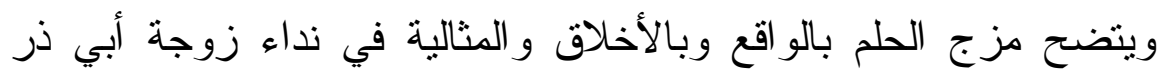
الغفارى فى مسرحية (أبى ذر الغفارى ) يا سيدي .. ومبعث الفكر الثريف .. يا حلم الرجال الخصيب .. ومنبت الفكر الثريف ل. .. وهذه المرأة مندينة

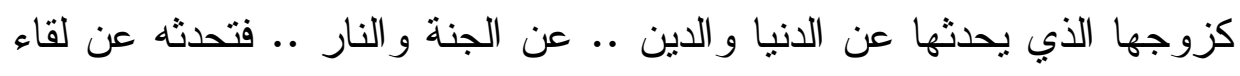

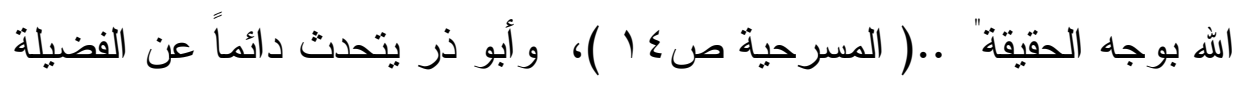

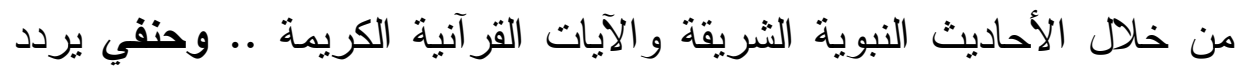

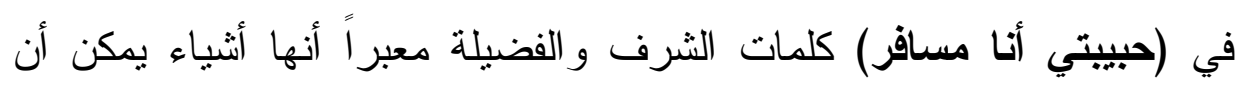
يدمجها معا كي يصنع بها المقاومة والمساومة، كما أن السيدة تعلن أن اللهو

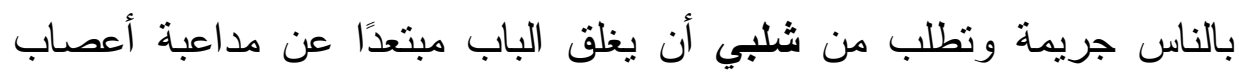
الآخرين .. ويهتف مقبول أن تحبا المواقف الثريفة، وتعلن المرأة البدينة أنها سوف نتبر ع بملابس ابنها للأو لاد وبملابسها القديمة للفتيات.

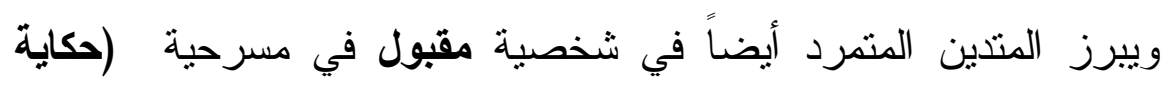

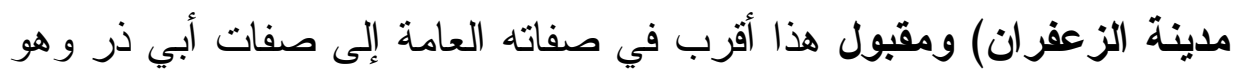




\section{د. ش شيماء فتحي عبدالصادق}

يهتق: يا حبيبي يا رسول الله، الإنسان إذا صار عبداً وصارت الأمة نعاجاً اتلهف للقائك يعبرني الزمني، أحبيتك يا صاعداً محملاً فوق أكتاف الرجال المنحنية ظهورهم من التعب، يا نبي الله يا حبيب الله يا حبيبي". (المسرحية

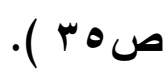

وتتضح شخصية المثالي الأخلاقي في شخصية الذي يحاول في مسرحية

(حبيتي أميرة السينما) فهو رجل ينسلخ من أحلامه القديمة .. يبحث عن امر أة

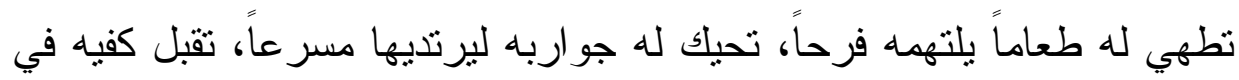

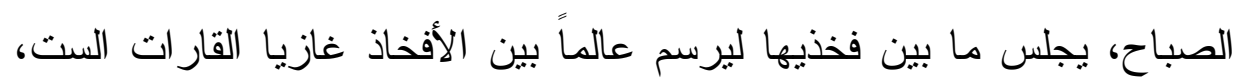
إنه أمل يسعى إلى صنع عالم مثالي للأميرة البريئة، حتى العالم البسيط لديه متمرداً.

و هذه التركيبات السابقة للتمرد في مسرحيات السيد حافظ هي أساساً

نزكيبات فنتازية، فالثوري السلبي والحالم المثالي هو إنسان فنتازي يطير من فوق أروقة الو اقع الذي يعيشه ويحلق في سماء ينشدها، يركب الأشياء ويصوغ منها تعبيرات جديدة، وعو الم الخيال و الفنتازية عند المتمرد هما شيء و واحد لا لاء

ولعل أوضح مثال للمتمرد يتجسد في شخصية "ضياء" في "ج رجال في معتقل . .0 شمال حيفا"، فقد نتصوره لأول مرة مجنوناً، ولكنه إنسان يعيش

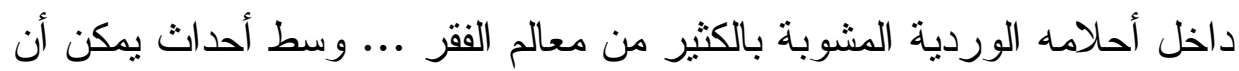
تحدث في أي معتقل، ولكن "ضياء" يحلم بحبيته ويحدثها عن السيارة الرولز رويس الحمر اء التي تدوي وقد غطاها الضباب الأبيض .. وقد وصفه زملاؤه بالجنون، لكننا لا نستطيع أن نحدد هل هو صورة من البطل الحالم الذي يبحث عن الأمل وسط آخرين يعيشون في أرض المعتقل، إنه يحاول أن يعبر برأسه وروحه خارج هذا المكان المحدود بعيداً عن الجدران .. هذه الجدران الهشة مصنو عة من ثوب حريري ينفذ منها شعاع الثمس .. يتحدث عن أمو اج البحر 
أو العو اصف، وهو ينطق من وقت لآخر بعبارات أثنبه بالأمثال المعروفة

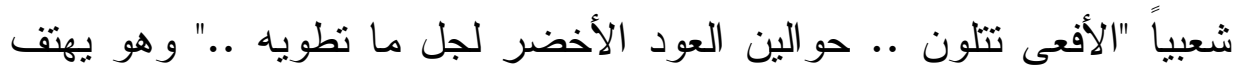

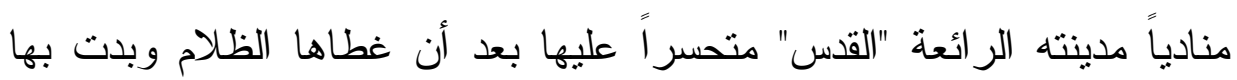
الصلبان بهتانة، كنو عن التمرد المستمر و الثثورة الداخلية.

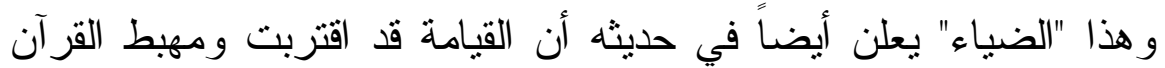
أصبح غريبًا. وها نحن الآن في مجتمع تتبؤي .. ويبدو أن بطلاً ثورياً قد تكلم وتعلم من

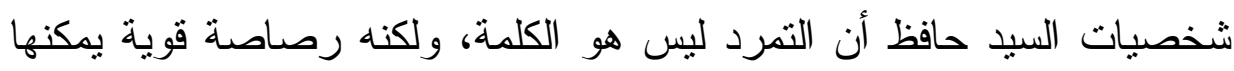

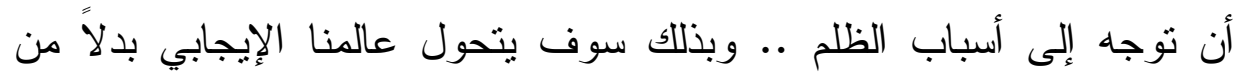

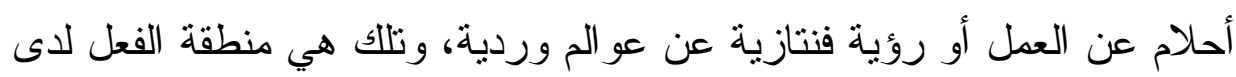

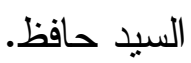
التجريب بين تجديد الروئية و العنوان:

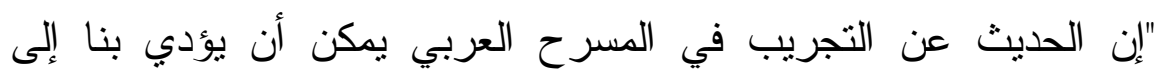

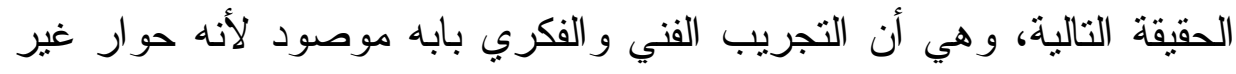

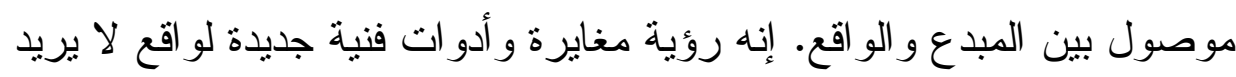

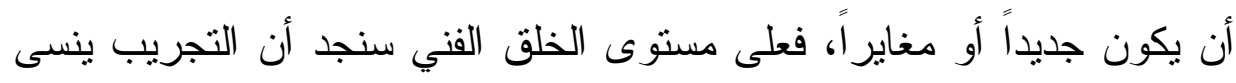

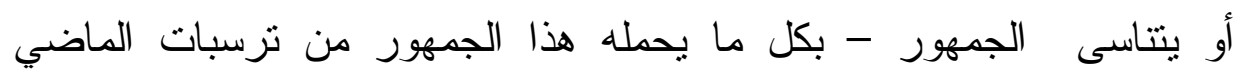

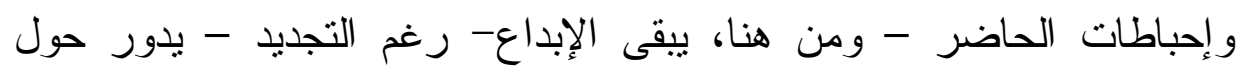

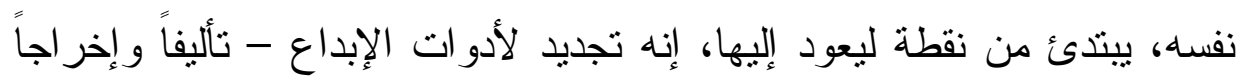

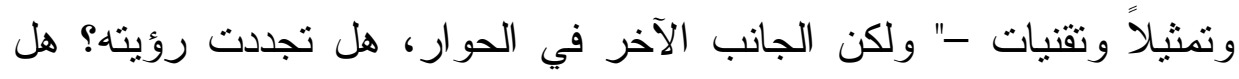

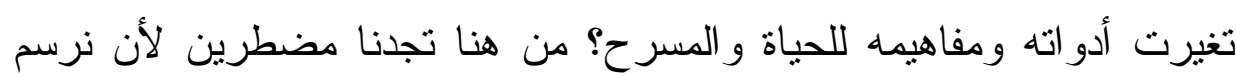

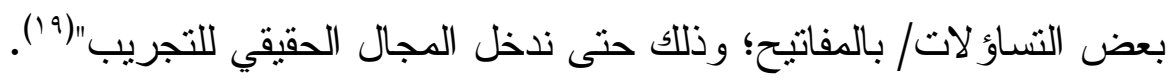




\section{د ـ شيماء فتحي عبدالصادق}

- هل يمكن للتو اصل أن يكون حقيقاً بين إبداع تجريبي منقدم، وجمهور

$$
\text { مسرحي متخلف؟ }
$$

- كيف نسعى إلى خلق خطابات فكرية وفنية مغايرة ثم نعمل على إيصالها إلى الآخر ، في الوقت الذي لا وجود فيه لهذا الآخر المغاير، إن الكتابة الجديدة تتطلب بالضرورة قر اعة جديدة. "-التجريب بالأساس ضرورة بأسة، فالواقع عندما يزداد نركيباً وتعقيداً فإنه

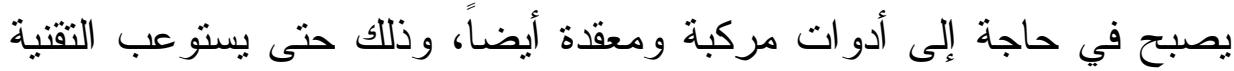

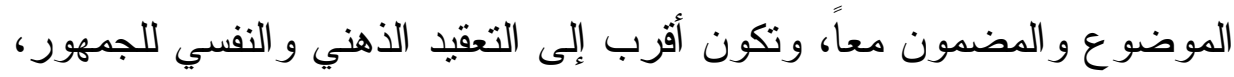
فهل وصل الواقع العربي إلى مرحلة دقيقة مركبة ومعقدة حتى نبحث له عن

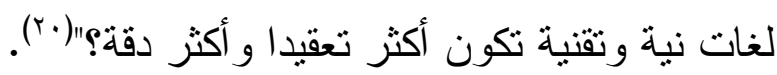
خاصة أن الإبداع الحقيقي يقف دائما في مو اجهة السلطة، هذه ونه السلطة

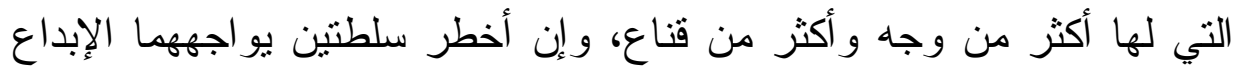
العربي هما سلطة الدولة وسلطة الجمهور، فالدولة تفرض مغازلتها و الدوران في أفلاكها، أما السلطة الثانبة فتعبر عن ذاتها مسرحياً من خلال لعبة إرضاء لهاء

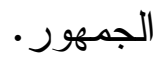

وبم إن الإبداع في المجتمع العربي مطالب بأن يكون تابعاً للسلطة .. لذا هو يبقى قانعاً باجتر ار المفاهيم القديمة. مع أن الإبداع الحق يقوم أساساً على الحرية، حرية المبدع في الخلق،

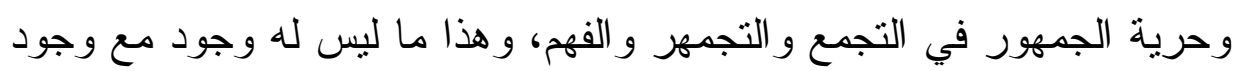
السلطة في تجلياتها المستبدة و المنسلطة.

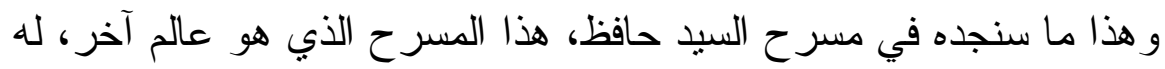
أزمانه المغايرة و أثخاصده وطقسه عالم يختلط فيه الو اقعي بالحلمي و التاريخي بالأسطوري و المحسوس بالمجرد و المشخص بالمعنوي، هذا العالم له بنيته 


\section{غر أيبية العنوان}

الخاصة، سواء في التركيب الذهني و النفسي للثخصيات أو في اللغة والحدث و المو اقف، وأيضاً في العنوان الغريب، وفي لعبة التمرد الأصيلة في كتاباته.

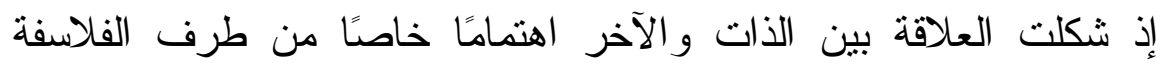

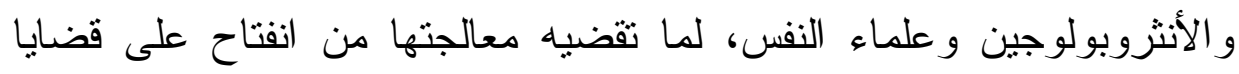

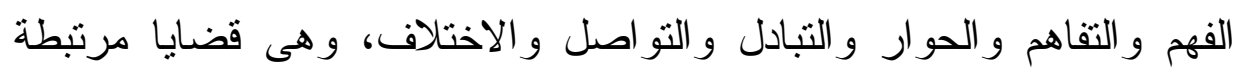

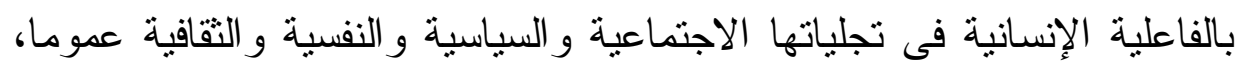

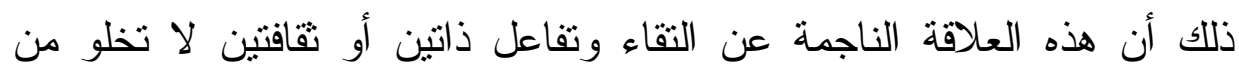
مأزق و التباسات تهم طبيعة العلاقة وطرفها. وقد لعب عليها السيد حافظ بوعي لهاه شديد من العناوين إلى متن النص المسرحي، خاصة تسمية العنوان بالثخصية أو بعضاً من صفاتها وظروفها.

ولو نظرنا لـــــــيجموند فرويد "هو يسمى النفس البشرية "بثخصيتها

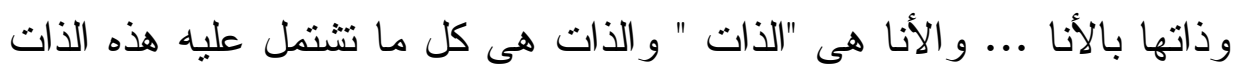

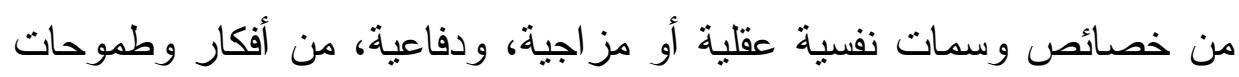

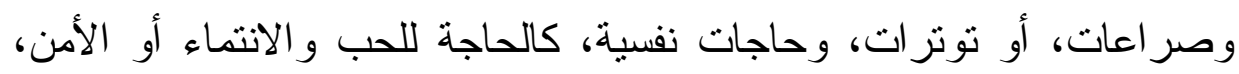

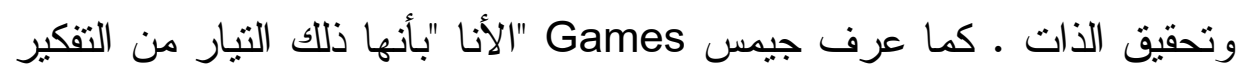

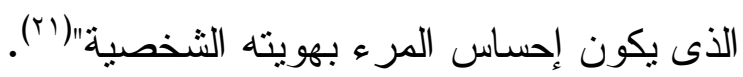

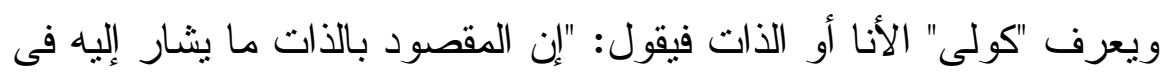

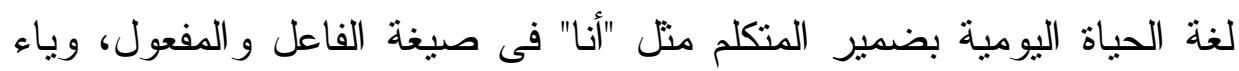

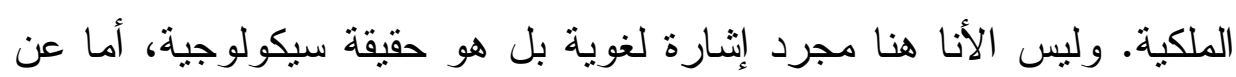

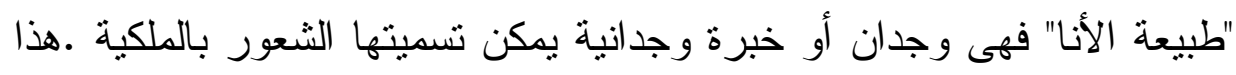

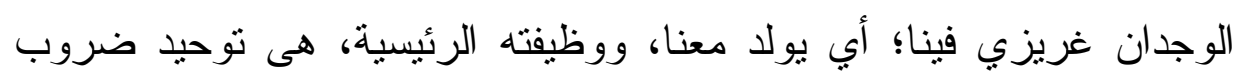

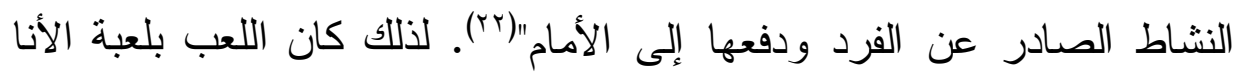

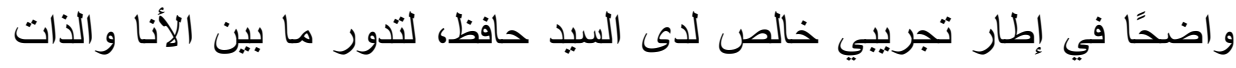

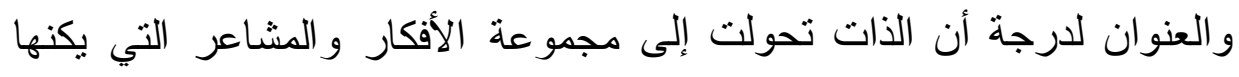




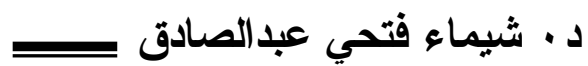

الفرد لنفسه كموضوع تأمل. وللذات محتوى يتضمن الانتماء للجماعات الاجتماعية سواء العرقية (أبيض - أسود) أو النوع (ذكر - انثى) أو غير ذللك "(rr) من الثخوص التي لعب بها و عليها السيد حافظ في مسرحه التجريبي و عناوينه الغريبة.

إذ إن التجريب مر ادف التغيير، فهو يظهر دائماً في المر احل الانتقالية وهو مرتبط بالوضع الاجتماعي المحدد، مكانياً وزمانياً وليس مطلقًا، إنه الكثف عن الئ اللامنطق و اللامعقول في المجتمع. ارتباط العنوان بالنص المسرحى :

إن العنوان يضع اللحظة الأولى فى علاقة القارئ بالنص ، فإن نجح فى اجتذاب اهتمام القارئ واستطاع لفت انتباهه فقد أدى واحدةً من أهم وظائفه ( استقطاب القارئ )، إذ إن العمل لا يمارس دوره و لا يكون فاعلاً إلا فى ونى حضور القارئ من هنا كان العنوان لحظة الاتصال الأولى بين القارئ و النص. كما تظهر طبيعة علاقة العنوان بالنص وبالقارئ من خلال أثز الظرف هنئ التاريخى فى إنتاج العنوان ، وكذلك من خلال تتبع الظروف الاجتماعية الفاعلة فى تلك المرحلة ، إن العنوان فى بعض جهاته انعكاس مباشر لتلك الظروف ، وتعبير موثوق عن العو امل التاريخية و الاجتماعية الفاعلة فى تلك المرحلة ، إن اختيار مفردات العنوان ، و آلية صياغته ، وطريقة كتابته وتتكيله كل ذلك يحيل إلى ظروف تاريخية و اجتماعية وثقافية تلفت الانتباه وتستدعى النظر و التحليل " إن علاقة العنوان بالنص يمكن رصدها من زوايا متعددة فى عصور متباينة،

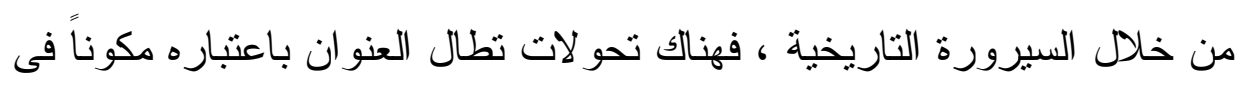

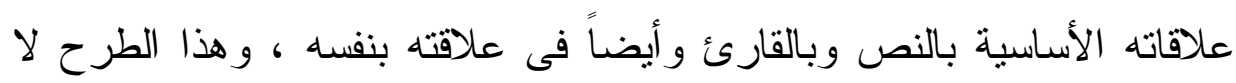
يقول بالانقطاع أو بتجزؤ التاريخ إلى مر احل بقدر ما يدعو إلى إدر الك علاقة

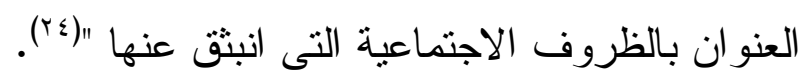


فنجد أن شخصية أبي ذر الغفاري فى مسرحية ظهور و اختفاء أبى ذر لفران الغفارى ذللك (الصحابي الجليل المعكك بسيف الحق القابض على الجمر)، إنه يز اوج بين كلمة الحق و السيف الذي يحمي الحق وينصره، هذا البطل الملتحم بالناس وبقضاياهم اليومية يعيش النفي و الغربة، وذلك شيء طبيعي ما دام يحمل

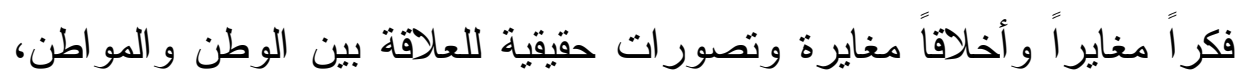

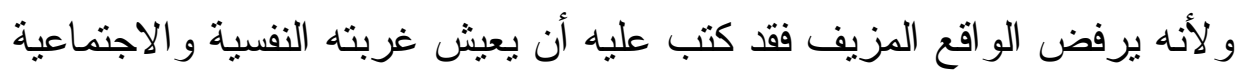
و الفكرية. فهو الثخصية الأساسية و التى تمنل صلب العنو ان ان ويحمل دلالة معينة

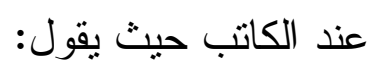
"وتموت غريباً في أرض اله الواسعة ... وتموت غريباً بين خلق الله

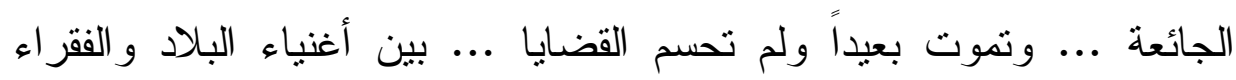
العر ايا". (المسرحية صلو و ) ). تتكرر كلمة (الموت) ثلاث مرات، وتتكرر (غريبا) مرتين وتنقى الكلمات الأخرى هي (أرض الله الواسعة وخلق اله الجائعة و الفقراء العرايا و أغنياء البلاد) وعن التتقيب الجاد في ثنايا النص عن المعاني الدفينة واستتطاق المكتوب للإلمام بالأبعاد السياسية والاجتماعية التي تحيل إليها رموز النصان النصا،

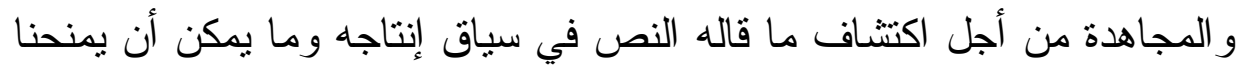
في سياق تلقيه الآني، خاصة في عقد التسعينيات من القرن الماضي.

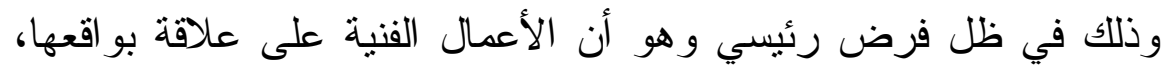
ولكن الصيغ التي تتأسس عليها هذه العلاقة تتعدد؛ فليس بإمكاننا أن نحدد أنماطاً لهذه العلاقة؛ لأن كل عمل يحاور و اقعه على نحو خاص؛ وفقاً لطريقة تمنكه

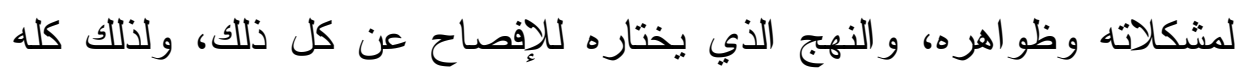
لا يمكن تصور علاقة ميكانيكية بين المنتج الفني وسياقه، خاصة أن الآثار الفنية المهمة تتفصل، إلى حد معين، عن ظروفها عليكانه التاريخية. 


\section{د · شيماء فتحي عبدالصادق}

ومع ذلك يبقى لنا أن نؤكد على أن النص ليس انعكاساً آلياً لأحداث مائلة

في سياقه؛ بقدر ما هو تمثيل خاص لهذا السياق يخضع لمتغيرات عدة، منها: طبيعة الحقل الفني، و الموقف السياسي الاجتماعي للكاتب، وحدود حرية التعبير في مجتمعه؛ و أي نص بالرغم مما يحفل به من إسقاطات على و اقعه؛ فإنه و هذا شرط محوري لجودته وخلوده - لا بد أن يصلح للتلقي في سياقات أخرى، وإلا صار وجوده رهناً بمرحلة لا يجاوز ها، فقي كل عمل ما هو وقتي عابر وما هو أزلي دائم. ومع ذلك فالو اقع السياسي والاجتماعي يظل جزئياً في هودي تأثنيره على تتكيل قسمات العمل الفني؛ فتمة مؤثرات أخرى تتآزر وتتعاقب على وعي المبدع وليخرج النص المسرحي في صورة شهية للمنلقي. (بين كل رجل ورجل رجل من الثرطة السرية، وبين صوتلك وصوت الناس، وبشير المؤلف ... التضليل والضالص المبين)، يشير إلى وجود المعنى ووجود الحق و الحقيقة، ولكن هناك من لا يريدهما فيعمد إلى التضليل و التجهيل حتى يغيب الوعي ويسود الجهل وتبقى الدنيا كما هي الدنيا ساكنة من غير تقدم، وجامدة من غير تغير و لا تحول.

إن المسرح قادر على إعادة النظر في أكبر القضايا، ومناقشة أرسخ المفاهيم و التصور ات؛ فالمسرح الحقيقي تقويض للأفكار المهزومة التي تحد من خيال الأفر اد و المجتمعات، وتثئ التطلعات نحو عالم أجمل وأرقى. ورؤية الموت على هذا النحو التي تُطرح في ثنايا الجمل السالفة هي دعوة ضمنية للتخلي عن النظر إليه بوصفه غياباً - أو بالأدق الغياب - و انسحاباً من عالم الأحياء، إلى رؤية أكثر رحابة عندما يتحول إلى حضور ولكن بطريقة مخالفة للحضور الجسدي الحيوي الملموس، وعلى هذا النحو يضيء النص جانباً مغيباً في التجربة الأهم على مدار حياة الإنسان، ويدعو - في الوقت نفسه - إلى قبولها وتأملها دون التتبث بظاهر ها القريب والاكتفاء بالحداد و التهالك على الى 


\section{غر ائبية العنوان}

ففى مسرحية (كبرياء التفاهة في بلاد اللامعنى) أثارت جدلاً لا حد له ..

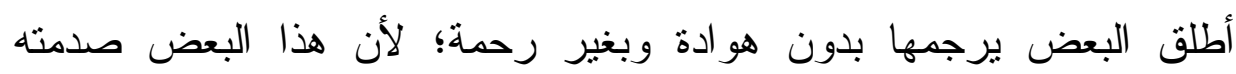

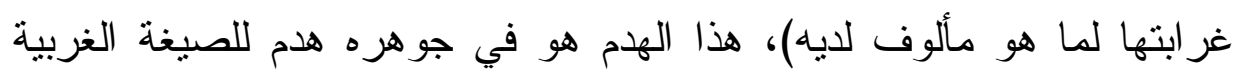

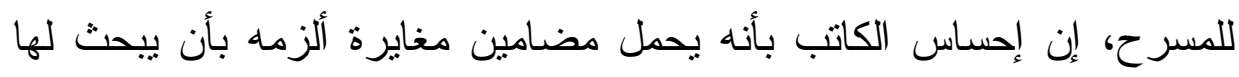

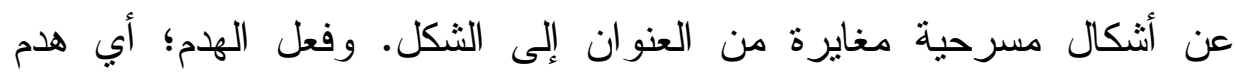

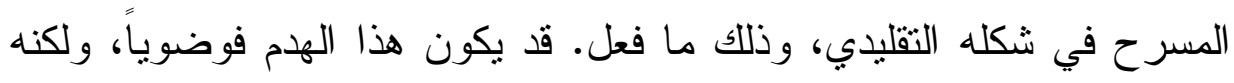

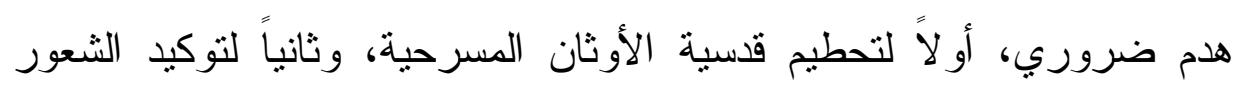

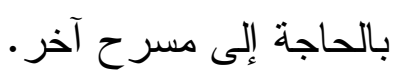

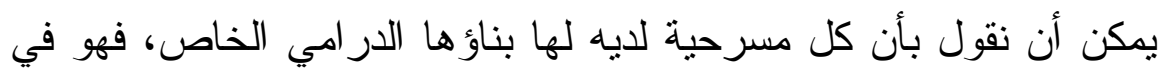

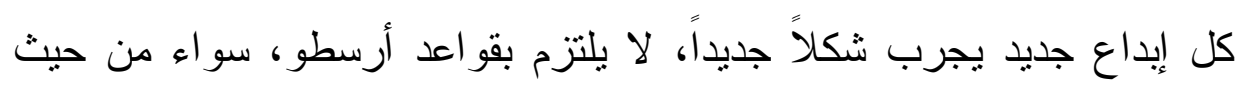

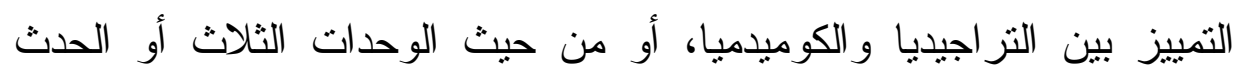
وتطوره التصاعدي ونتأزمه و انفر اجه، أو طبيعة الثخصيات ومفهوم التر اجيديا،

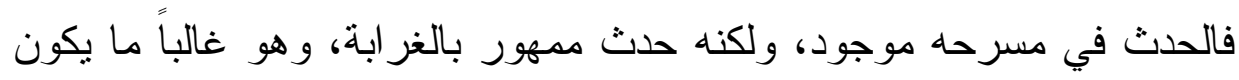

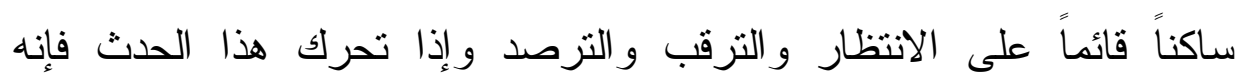

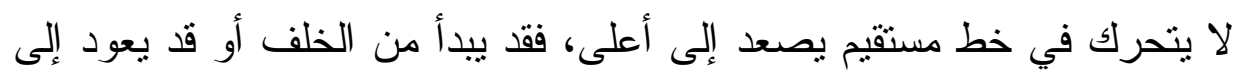

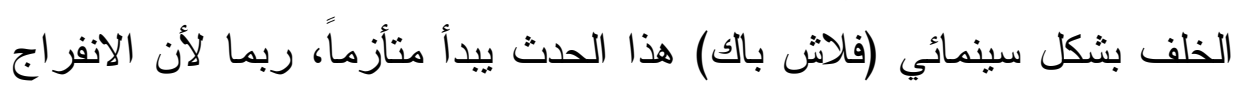

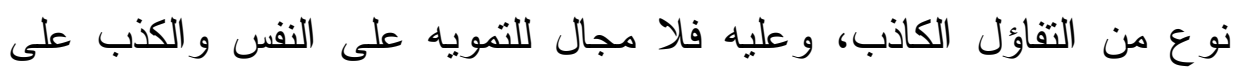

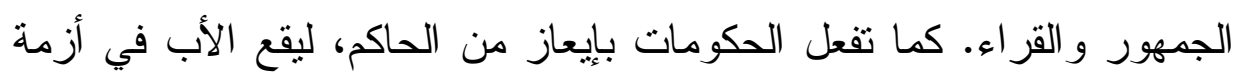

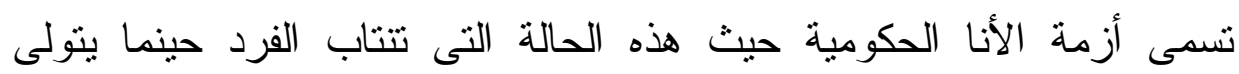

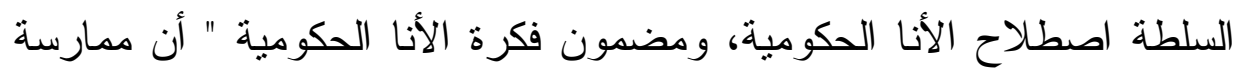

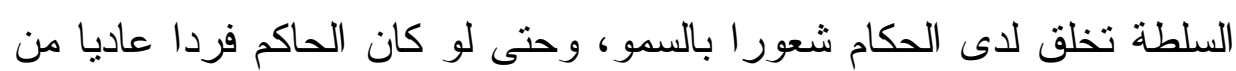

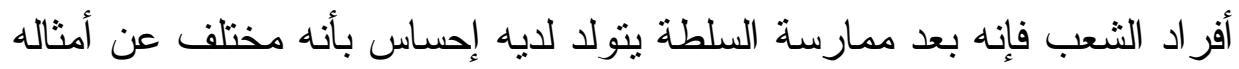

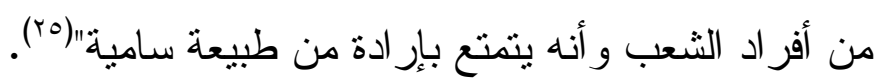


د . شيماء فتحي عبدالصادق حس

يبدو أن الأنا الحكومية لها تجلياتها في العديد من دول العالم العربيه سواء لاستخدامهم العنف أو الاستبداد و القهر المادى و المعنوى إلى الوسيلة الطبيعية للسلطة من حيث احتكار ها وشر عيتها. و هذا ما كان يؤرق السيد حافظ ويخرجه في نصوصه المسرحية التي نتنعل منذ العنوان. المكان المعروف والمجهول:

المكان في مسرح السيد حافظ هو مكان مسرحي خاص، مكان مرتبط بالمسرحية ، أما الزمن فهو متحرر من الساعة ومن عقاربها، إنه الزمن الحلمي و الأسطوري، وقد يحدث أن يكون للمسرحية تاريخ محدد، ولكن هذا التاريخ يظل غائباً كوقائع لها ارتباط بمكان محدد وزمن محدد وأثنخاص معينين، فالزمن في مسرحية (حدث كما حدث ولكن لم يحدث أي حدث) يدور (أثناء الحرب العالمية الثانية، و المكان مخبأ عام في أحد أحياء الإسكندرية)، أما في مسرحية (الحانة الثشاحبة العين تتنظر الطفل العجوز الغاضب) فالمؤلف يحصر الزمن فى (بعد أحداث خمسة يونيو - الفترة الأخيرة من القرن العشرين الفترة التي تبدأ فيها الثمس في الاستغراق و الظلام يزحف). أما المكان في المسرحية فهو (جزيرة السمان - في صحر اء رام الله - في خطوط المواجهة "السويس الإسماعيلية" في داخل الأرض المحنلة - في بقاع أخر "من المجتمع")، وبرغم هذا التحديد فإن السيد حافظ لا يهمه أن يقدم صورة و اقعية وطبيعية للمكان و الزمان؛ لأن الأساس لديه هو ألا يكون الديكور و اقعياً وذلك حتى لا يسجن ذهن المتقرج داخل بؤرة و احدة ضيقة . وتدور المسرحيات الأخرى في إطار مكاني / زماني غريب. فمسرحية (ظهور واختفاء أبي ذر الغفاري) تقع أحداثها في دولة "فردوس الثورى" (الفردوس الأخضر سابقا)؛ أي أنها دولة لها موقع جغر افي على خريطة العالم، فالأسماء قد تتغير، ولكن المسميات تبقى كما هي، حاضرة موجودة وقائمة، فالمهم إذن ليس الدولة ولكن ما يقع داخل الدولة من أحداث وممارسات. و إذا 
كانت التسمية غريبة فإن الأحداث و المواقف والثخصيات ليست غريبة. فالمؤلف يترك للمتفرج حق القراءة الحرة القائمة على الإسقاط، إسقاط مكانه

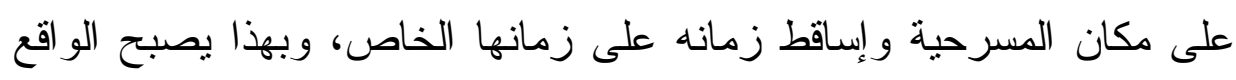

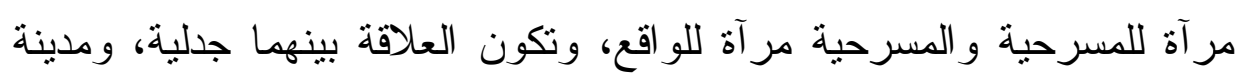

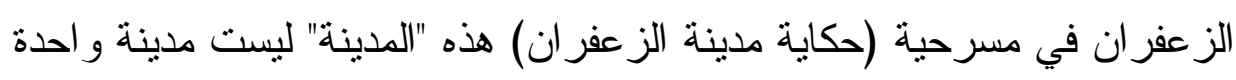

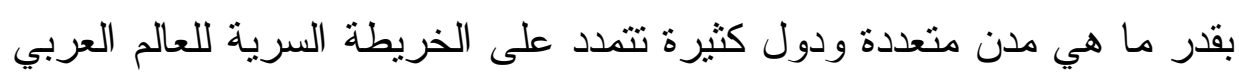

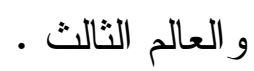

فمسرح السيد حافظ يثير مناقثات واسعة عنيفة فهو يقتحم عو الم كثيرة ويمس مفاهيمنا الفنية و الاجتماعية و الفكرية و السياسية بصورة قوية ولية مباشرة، ومن هنا كان لا بد أن يثير مسرحه عاصفة من الآراء المؤيدة والآراء

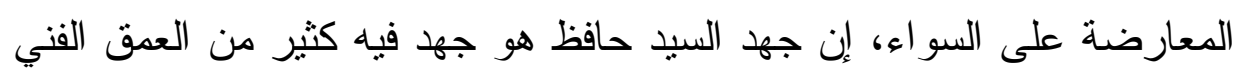
و الأصالة و الحضارة. و هذا هو المسرح الحقيقي لأنه يعبر عن المشاكل و الهموم التي تشغل كاهل

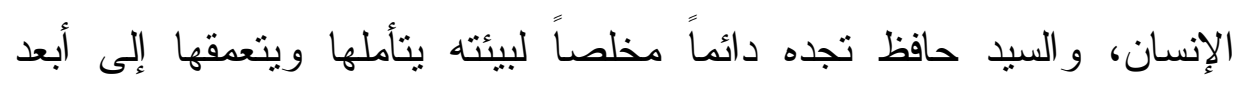

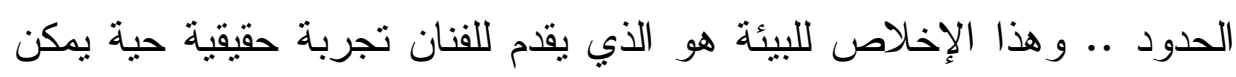

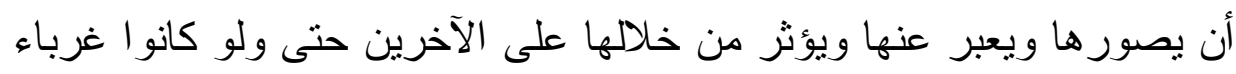
عن هذه البيئة. ومسرح السيد حافظ يناصر كل ما هو مستعبد، ويناصر البحث عن الحرية

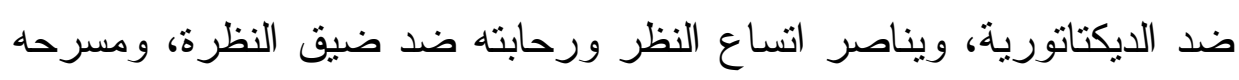

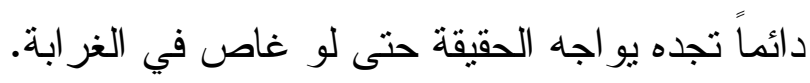
و السيد حافظ لا يلتزم بحرفية تعليمات وحدات المكان و الزمان الأرسطية، ولكن نتصب اهتماماته على تحرير المسرح كمسرح من الأثكال التقليدية 


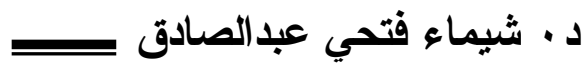

عنو ان المسرحية "كبرياء التقاهة في بلاد اللامعنى"، و الواضح أن هذا العنوان من اللحظة الوحيدة النادرة التي يلتقي فيها الصحفي بإنسان ما، ثم بـاء يتحرك المذيع إلى الأسرة التي يقيم معها في غرفة ممسكاً بجهاز التليفزيون بانيان و هذه مع لقاء المذيع بزوجته هما اللحظتان الوحيدتان فقط اللتان بحدث بهما التواصل .. على المستوى الثكلي أو مستوى العلاقة التلامسية بين بطل هذه المسرحية، وبين باقي الثخوص، لكن باقي الثخوص تمارس الفعل المسرحي،

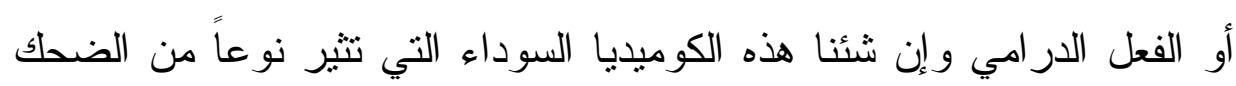
لكنه ضحكا كالبكاء .. ضحك مأساوي .. لم يحدث أي تو اصل أو أي لقاء على لتى الإطلاق .. ما بين البطل وبين باقي الثخصيات. مسرحية (ظهور واختفاء أبي ذر الغفاري) ... (ثقافة العبث المسكوث عنه)

إذا كانت الثقافة تقدم للإنسان مجموعة القيم و الأعر اف التي توجه سلوكه من ناحية، وتقدم له معايير الحكم على الأشياء من ناحية أخرى، فإنها - في الوقت نفسه - نتيح له قدراً من الاختيار؛ ليفضل مسلكاً على آخر، أو عرفاً

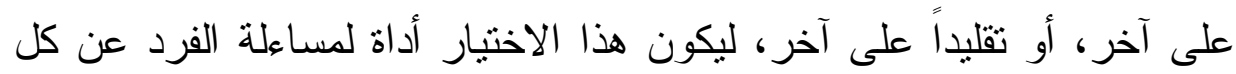
تصرفاته، لكن الاتساق الذي يحكم مفردات الثقافة عموماً، يصيبه نوع من الخلل و التمزق الذي يضيق أو يتسع، وقد يتحول هذا التمزق إلى نوع من (التتافر) الحاد الذي يهز الثقافة هزاً عنيفاً، ومن ثم يتحول الاختيار الذي يمتلكه الإنسان لينظم مسلكه الحياتي إلى عملية عشو ائية تهدد صاحبها بالضياع، وتهدد و اقعها بالفساد و العبث.

"وتزداد هذه العشوائية العبثية مع وقائع الحروب توابعها التذميرية؛ إذ تتحول الثقافة إلى طبيعة (سوقية) تحكمها قو انين البيع و الثراء، ومن ثم تتغير قائمة القيم، ويكون في أعلاها البحث عن المال بكل الوسائل المشروعة، 
و البحث عن المتعة الحلال و الحرام على حد سواء، بل ينكسر الحاجز بين

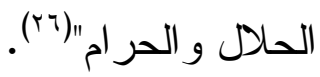

و الحقيقة أن ذللك كله يندرج في سياق إطار عام يعيثه العالم اليوم؛ إذ إن العالم بقدر ما فيه من انتظام تتخلله الفوضى التي لا تحتكم إلى قانون بعينه

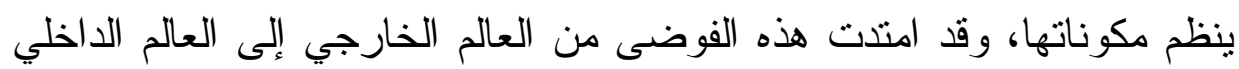

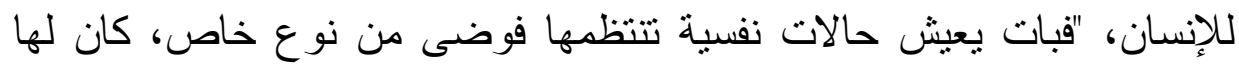
ناتجها السلوكي الذي يشوبه الاختلاط والعبث، ومن ثم اتجه هذا الإنسان المعذب بتناقضات الداخل والخارج، إلى الخلاص من هيمنة النظام الذي يقيده،

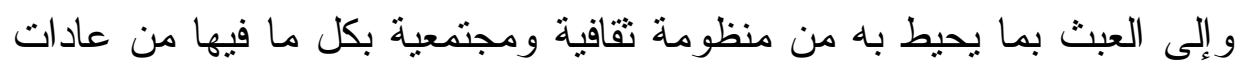

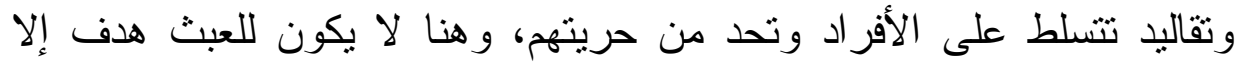

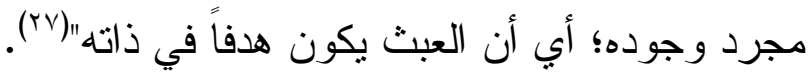

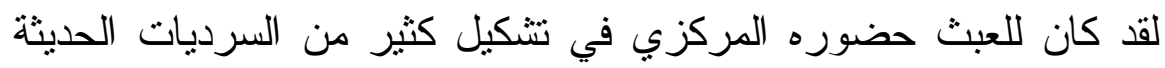

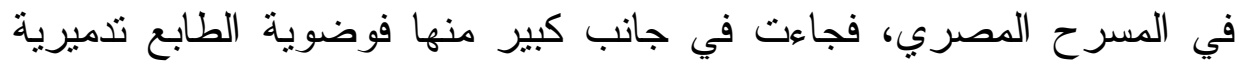

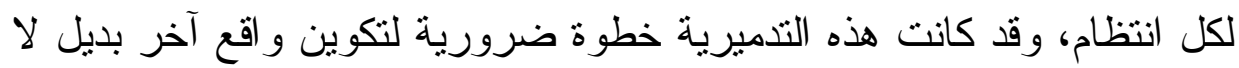
يعرف الحدود أو القيود.

و هنا يحل الاستثاء محل القاعدة، ويتحول المجتمع إلى منظومة قابلة

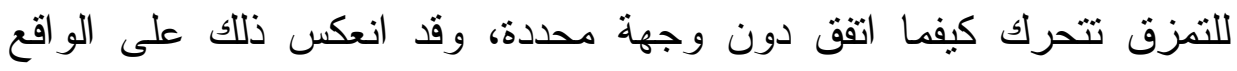

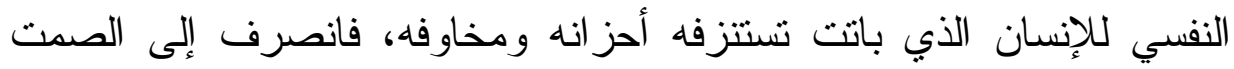

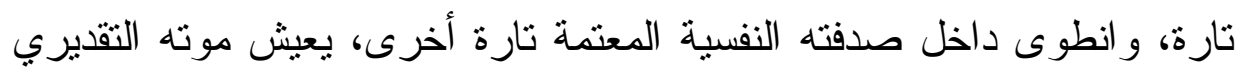
تمهيداً لموته الفعلي. تولي. ولكن ما مدى انعكاس ذلك على النصوص المسرحية لدى مسرح السيد

حافظ؟ 
لقد أصبح العبث صاحب السيادة الإنتاجية للسلوك والإبداع، وتوجيه حركتهما، ومن ثم أصبحت فوضوية بعض النصوص وعبثها، صورة لاختلاط الو اقع الحياتي وتخلخل مفاهيمه، و اضحة الدلالة لدى السيد حافظ بشكل لا تخطئه العين.

بدرجة جعلت من هذه النصوص تجسيداً لعبثية الواقع، وما نتج عنها من قلق على المصبر الذي ينتظر الإنسان في مواجهة هذا الكم الهائل من الحماقة،

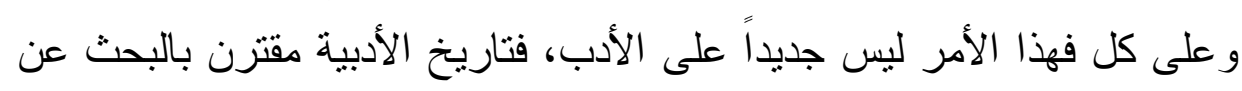
المناطق المظلمة في العالم، وكثف ما بها من عبث وفساد، ومن ثم يتحول منثل هن هذا الأدب إلى عملية تطهير بالمعنى الأرسطي، تساعد المجتمع على التخلص وكل

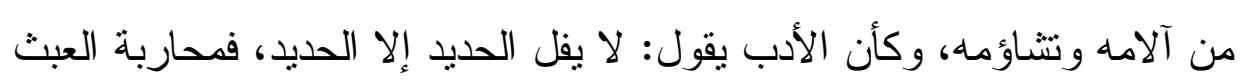
تكون بمزيد من العبث. وبرزت في العديد من التجليات لأكثر من مرحلة. "نتكل مسرحية (ظهور و اختفاء أبى ذري الغفاري) للكاتب المسرحي الطليعي (السيد حافظ) ذروة اكتمال النهج المسرحي التجريبي الذي نجده موزعاً في كل أعماله .. إنها تقوم في بنائها النسقي ومضمونها المتعدد الجوانب على معطيات عديدة من المسرح السياسي ومسرح اليسار الجديد، مسرح التحريض فه و الدعوة إلى فعل وتحديد موقف من واقع غير معقول وغير إنساني، ويتبدى

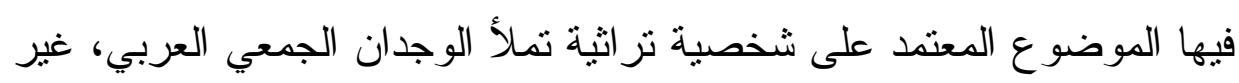
أنه لا تقدم تاريخ حياة أو سيرة بطل أو معالجة حدث تاريخي بل تنشد آفاق ومناقتشة الوضع المعاصر و المصير الإنساني للشعب العربي الواقع عديد من أجز ائه تحت سلكة ونبرة القهر و التعسف وحرمان الجماهير من الحرية و العدالة و الحياة الإنسانية المطهرة من الاستخله" "(^^). ولو عدنا إلى بعض من إبداعات السيد حافظ المسرحية مثل (الحانة الثاحنة العين تتنظر الطفل العجوز الغاضب) و (حكاية مدينة الزعفران) و(7 رجال في معتقل ... شمال حيفا) و (حكاية الفلاح عبد المطيع) و 
(علمونا أن نموت وتعلمنا أن نحيا) لوجدنا أنه مسر ح يعي جيداً علاقته بالنضال

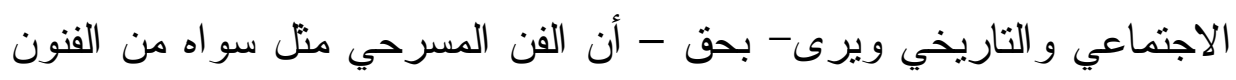

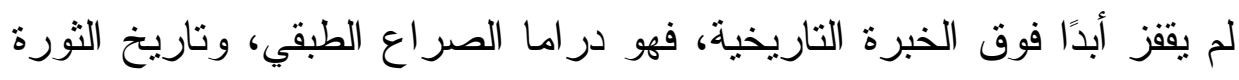
ينبئنا أن المستغلين و المقهورين عرفو ا مصادر استغلالهم وقهر هم قبل أن يتبلور

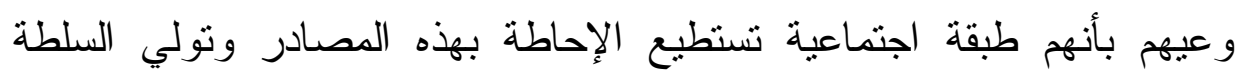
لصاحبها، لهذا فإن الفن- و المسرح بوجه خاص- كان في أوقات كثيرة فناً مقاتلاً.

غير أنه مسرح يعتمد على البديهية البسيطة، وهي أن المسرح يجب أن يكون مسرحاً بمعنى أنه يقدم مسرحية لا محاضرة أو قصة أو حشداً من الأفكار أو منشور اً دعائياً.

"ويتثكل النسق البنائي أو المعماري لكسرحية (ظهور واختفاء أبى ذر أبرا.

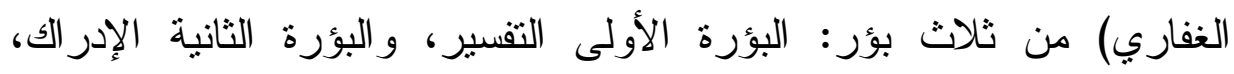

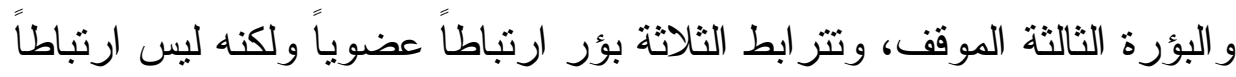
تقليدياً كبداية ووسط ونهاية، هو ارتباط جدلي بمعنى النقيض ونقيضه ثن ثن الفكرة

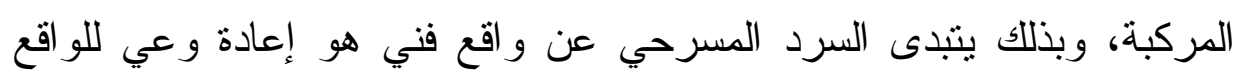

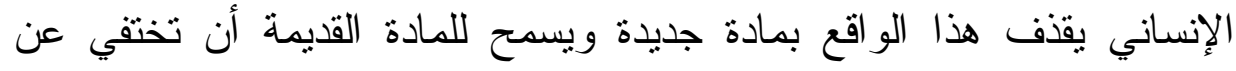

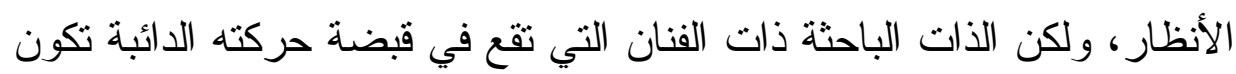

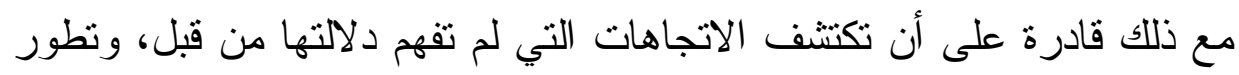
الأثكال الجديدة مرتبط أوثق الارتباط بهذا الاستكثاف النشط الدائب للو اقع (ب9).

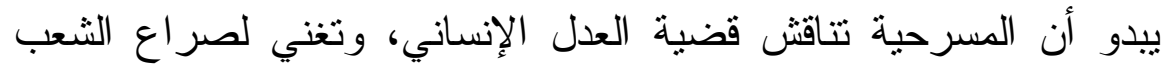

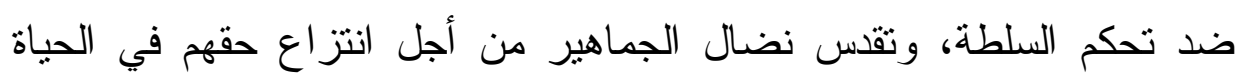
و العمل و الإبداع بتأكد حلم هؤ لاء البسطاء في حلم أبي ذر الغفاري. 
د · شيماء فتحي عبدالصادق عبـ

"قد كنت أحلم بالكلمة - السيف - بالكلمة السوط في يد المظلوم تقلم الظالم، لكن العالم ما بين تسامح عيسى و النوم على التخمة و اللذة، على الظالم أن يلقى من بده بعض فتات المائدة الممتلئة بحساء دو اجن أو لحم مشوي أو طير أخرس مقصوص الريش، لكن الطير الأخرس ينهض بعد أن ظل طويلاً مذبوحاً حين علق مشبوحاً في الحلق منتظر ضوء الفجر القادم أبيض كان أو لونيز

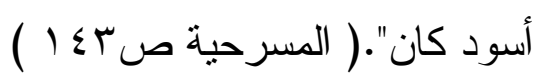

أما (المؤدي) يؤكد كيف بتصور الثعب أبا ذر الغفاري فيقول: "يا حليف البسطاء يا عدو للصوص، يا غريبًا في زمان همجي، يا فقيراً في مكان همجي؛ يا أبا ذر : تعال، و أنتظر كالضوء في جوف الجبال و انفجر كالضوء في سقف السماء، إنهم ينتظرونك كلهم ينتظرونك فاخرج الآن إليهم يا فقير اً منلهم،

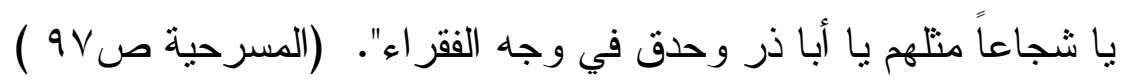
و أبو ذر يعلم الناس في الأسواق فيقول: "لا - لا يا أصحابي، الخوف هو

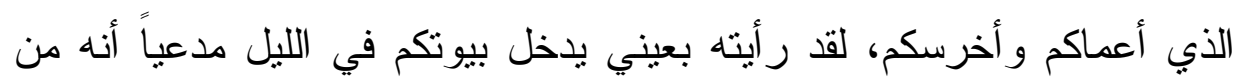
رجال العيون السرية (ويتقدم نحو المسرح). جئت لفصل الناس عن الناس.

لأنذركم، إنه عصر الموت للروح، هل تدركون أصحابي كيف ينفيكم الخوف وأنتم في بيوتكم تتضورون جوعاً وتتامون على الحزن و الفقر و الحاجة؟

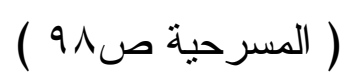
وتقع أحداث هذه المسرحية في دولة (فردوس الثورى) الفردوس الأخضر سابقاً أي أنها لها موقع جغر افي على خريطة العالم لأنها تقع على حدود

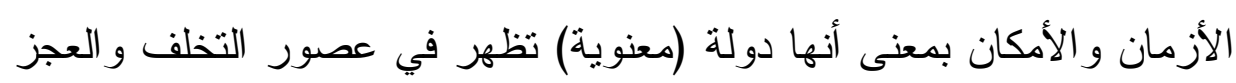
و القهر و الهزيمة. إنها مدينة تتنشر بها الثرطة و المخربون بحصون على الناس حركاتهم وسكناتهم، نجدهم في الأسواق و المقاهي وفي كل التجمعات. 
ففي هذا الجو الخانق و اللاإنساني تتردد أسطورة ظهور أبى ذر الغفاري،

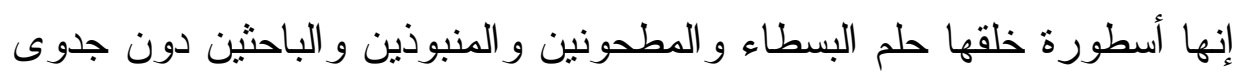

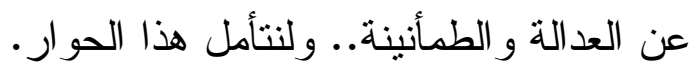

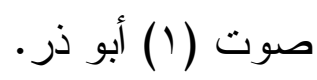

صوت (Y) من أين أتيت، من بيتك أم منفاك؟

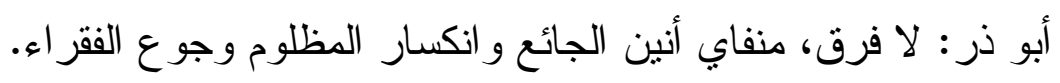

$$
\text { صوت (1) أنت بيننا و لا ندري. }
$$

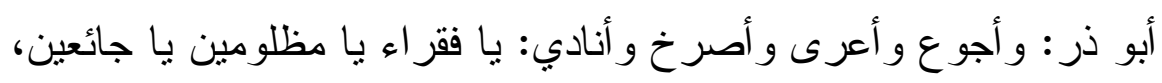

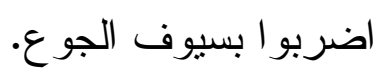

صوت (؟): يا أبا ذر لم نسمع نصحينك إلا الآن في هذه اللحظة، هل يقبل هذا العذر؟

صوت (0) لقد أصمنا الجوع و أخرسنا، الفقر يحدق في وجوههم ثم تتخير نبرة صوته.

لا لا يا أصحابي، الخوف هو الذي أصمكم و أخرسكم، لقد رأيته بعيني في

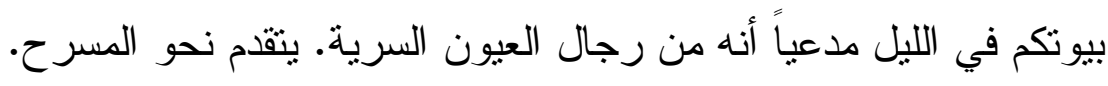
جئت لفصل الناس عن الناس، جئت (يخطو نحو المسرح) لأنذركم، إنه لأنه

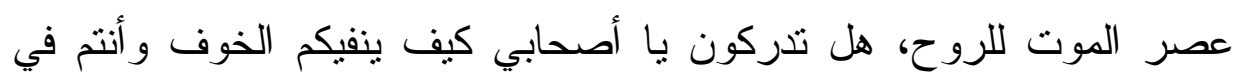

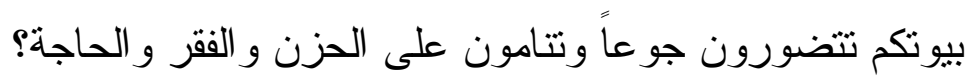

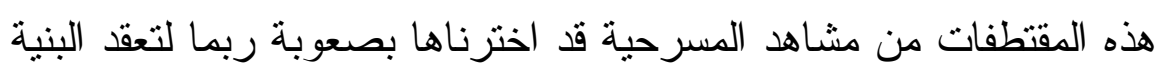
الثكلية في صياغات الزمان و المكان في هذا العمل.

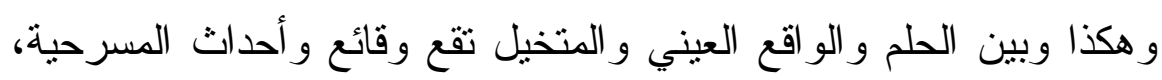

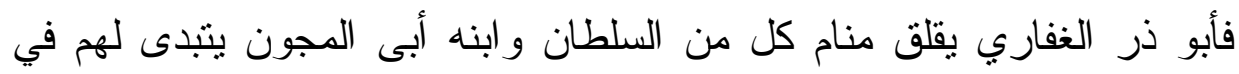
الحلم الو اقع يذكرهم بالجوعى و المظلومين. 
د · شيماء فتحي عبدالصادق بـ

يقول للسلطان: لا تأكل مال الفقر اء، أعتق نفسك من نفسك يعتقك الفقر اء ،

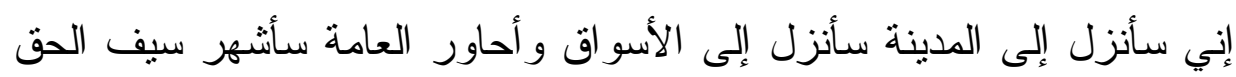
في وجهك سيلتف على عنقك حبل النار . ويأمر السلطان العسكر و المخبرين بالبحث عن أبي ذر وتندس عيون السلطان في كل مكان. فالعامة بدأت أصو اتها بالثكوى و التمرد ترتفع. قد قدم الخطباء الثناثة إلى المحاكمة، ورفض القاضي سيف الدولة الفاروق أن ينظر تلك المحاكمة لتلفيق التهمة ولأنه هو أيضاً ينزع إلى العدل ومن ون أنصار وتلامذة أبى ذر الغفاري وقد لفقت التهم في محاكمة شكلية، وجيء بالثهود و أدلى كل منهم بأن كل خطيب من الثناثة هو أبو ذر . - لقد فصلو ا القانون على مقاس الحكام. - باسم القانون .. نغلق أفو اهنا. - ونسكت على الظلم ونرضخ ونتحني ونساق إلى السجن. بعد أن بشكك كل و احد في الآخر يشك في بيته وفي جير انه، وفي أصحابه وفي رفقائه،

ثم يشك في المدينة يو اصل سيطرته على الناس، وفي النهاية بتو الد الثك و الخوف.

وما دام الناس يخافون .. فإنهم لن يتكلمو ا ويتعلمو ا الاستسلام لكل شيء. الظلم و القهر و الفقر و الانحناء، ثم يبدأ الثنك مرة أخرى دورة كاملة .. تبدأ من الثك وتتتهي بالثنك (الناس يتدخلون في الحديث). - لن نسكت هذه المرة. - سنتماسك في وجه الثك. - و علينا أن نقف أمام حائط السجن. 
(تدخل الثرطة وتلقي القبض على الرجل) ويستقر رأي السلطان و الحاثية على تدمير سمعة القاضي سيف الدين الفاروق، فيتهمونه بالرشوة و الإقلك و الفسق و الخبل بدليل أنه كان يندخل بشخصية أبي ذر الغفاري، ويتعامل مع فئه

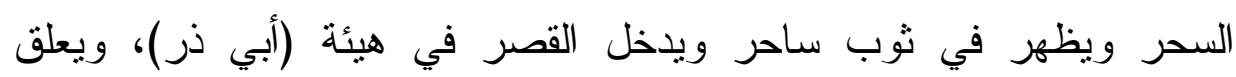
الكورس: انقسم الناس فريق مع (أبي ذر ) وفريق ضد وبد (أبي ذر).

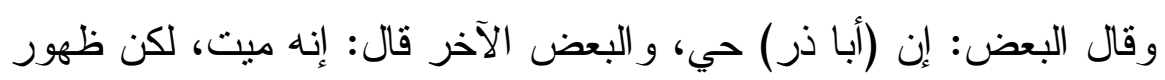

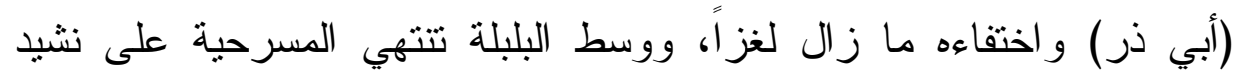
الكورس.

الكورس: لا (أبو ذر) لم يمت، إنه حي بين الناس إنه بينكم ... أيها الناس.

$$
\begin{aligned}
& \text { انظروا ها هو (أبو ذر) } \\
& \text { فنتو ا عنه } \\
& \text { إنه بينكم } \\
& \text { (أبوذر) بينكم } \\
& \text { فتتو ا عنه و احموه } \\
& \text { إنه بينكم } \\
& \text { (أبو ذر) بينكم أيها الناس (ستار بطيء) }
\end{aligned}
$$

"تلك مسرحية شجاعة تناقش قضية حيوية مطروحة على ساحة النضال

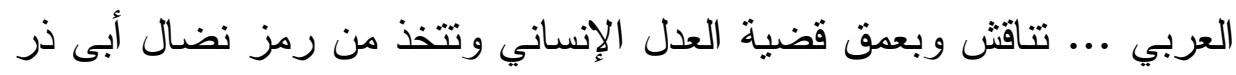
الغفاري الغائر في وجدان الثعب العربي منهجاً لتفجير قضية العدالة وحكم الشعب بالثعب العربي، منهجاً لتفجير قضية في بناء شكلي تجريبي ذاخر

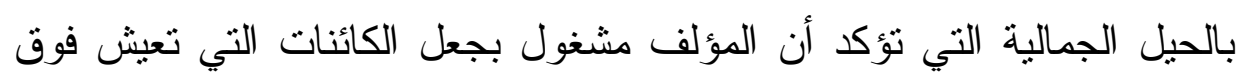

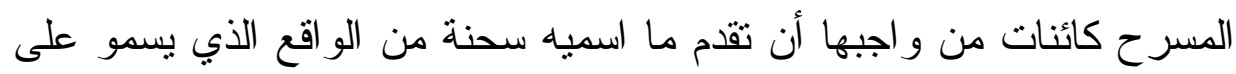


د · شيماء فتحي عبدالصادق عـ

الواقع الذي تجده عادة لدى الناس الذين تتصل بهم من جراء تجربتتا

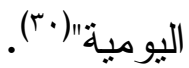

لذلك إذا انطلقنا من القاعدة التالية: أن الأسلوب ينبغي أن يكون و اضحاً سهلاً بعيداً عن الزخارف التي يحيا معها القارئ، إنها ركام من الأكاذيب المنمقة التي تفقد معها الكلمة معناها وتبدو اللفظة لا وزن لها. ولذا فإن كتابات السيد حافظ تتطلق من تصور ات و اضحة، فكأنه يدرك تمام الإدر الك أن الكتابة تتوجه إلى قلب القارئ قبل أن يقر أها بلسانه هو ؛ لذا

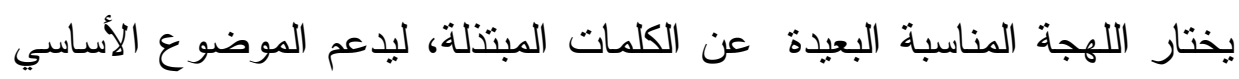
حتى يفهم القارئ البسيط و القارئ المثقف، وحتى لا يعزز غموض الموضوع بغموض في الأسلوب.

إن امتالاك الكاتب لقناعة شخصية في توظيف لغة شاملة الغرض منها التركيز على تفاصيل الأحداث، ومحاولة نقل الواقع في صورة مصغرة متحركة من خلال الشخصيات و أدو ار ها وتصر فاتها. إن ما يحتاج إليه العمل الفني هو الدقة المتتاهية في بلورة الأحداث ومن ثم

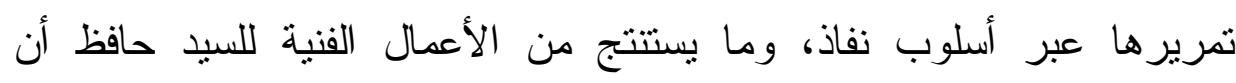
المضدون يساير - إلى حد كبير - جانب الثكل، فالأحداث لا تبقى معلقة في الفراغ، بل تخرج في صورة منفقة وما وضعه الكاتب من تخطيط بقو انينه، حيث تتسرب الفكرة مباثرة وبدون أي ضغط إلى ذهن القارئ فيتلقاها، ويحاول أن يتتبع ما تتطوي عليه من حقائق، بداية من العناوين الغريبة إلى لعبة الالنز ام

إذ إن "السيد حافظ كاتب مسرحي ملتزم بموقف تجاه جيله وو اقعه ومجتمعه العربي. وهذا الموقف لا يتمنل فقط في مستوى الالتزام كمعنى وسلوك، إنما يتجاوز ذلك إبداعاته الفنية في مجال المسرح. فهو كاتب بدأ الكتابة مبكراً (في سبعينات القرن العشرين) غزير الإنتاج منتوع الرو افد و الطرح"( آم). 


\section{$=$}

فهو من ناحية كاتب يعبر عن الواقع بمر ارة وحسرة يبغي الأفضل للإنسان

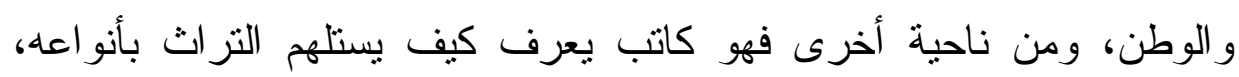

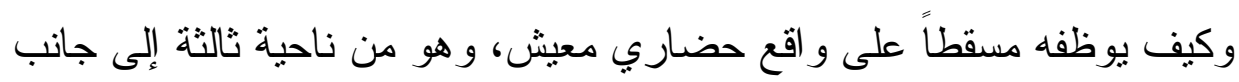
كونه كانباً درامياً سياسياً فهو من أو ائل التجريبيين، ولعل مسرحيته ونئه (كبرياء

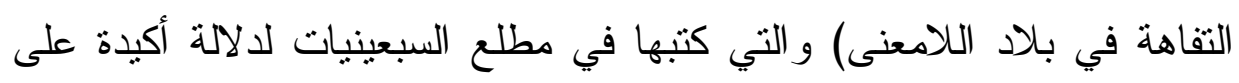

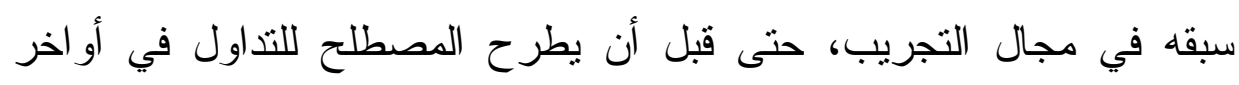
الثمانينيات.

بل إن أعماله متتوعة في شكلها ومضامينها، و إذا كان التتوع في المضمون قد طرحته تلك الأعمال وهي في معظمها تقف مع الإنسان وحلمه بالحرية

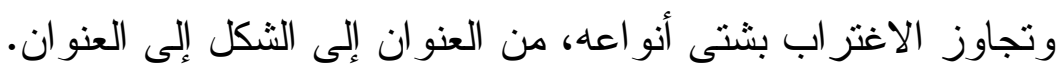

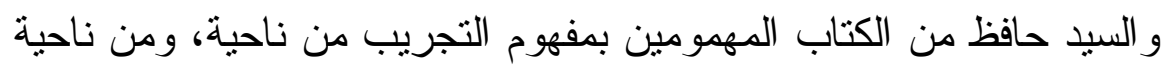

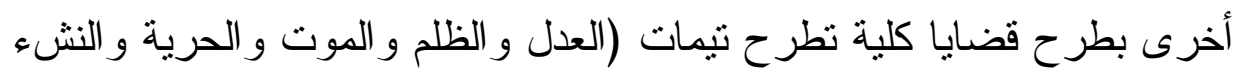

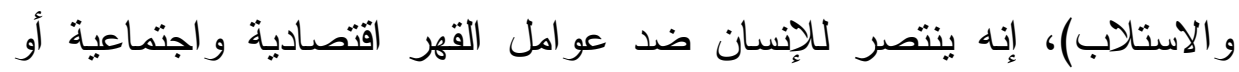
سياسية أو حتى كونية، ومن ناحية أخيرة وفي إطاره التجريبي فإنه بملك وعياً

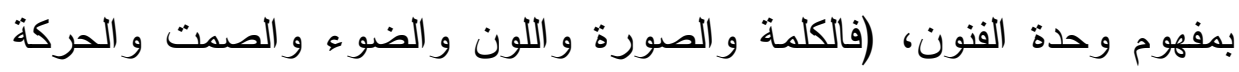
و الموسيقى) إنثكاليات يجرب في إطار ها أعماله المسرحية.

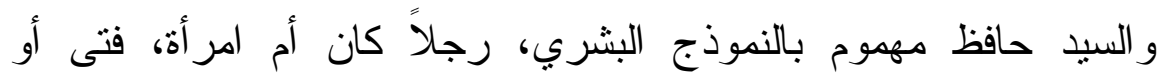

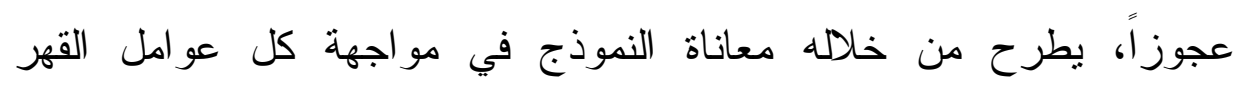
و الاستلاب.

العنوان ومفارقات الزمان و المكان:

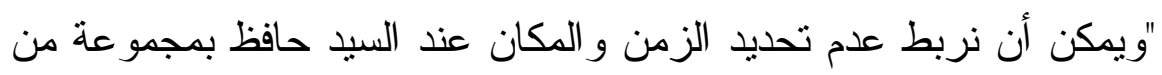

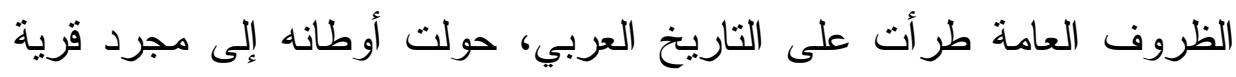
صغيرة لا نعرف وجودها بالضبط، فهي فضاءات نوحي بالغر ابة، وهذا يدفعنا 
إلى القول بتشابه أعمال السيد حافظ من حيث طريقة عرض الأحداث وزمنها

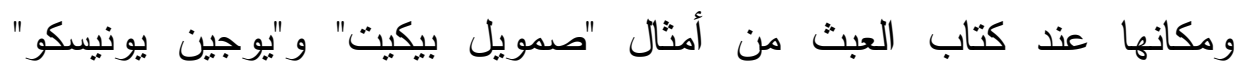
و "آداموف"، غير أنها لا تقيد فكرة اللامعقول، و إنما هي استجابة للمسر حس الجديد و الذي لا يوجد فيه زمان أو مكان محدد تذور فيه أحداث المسرحية و الأحداث

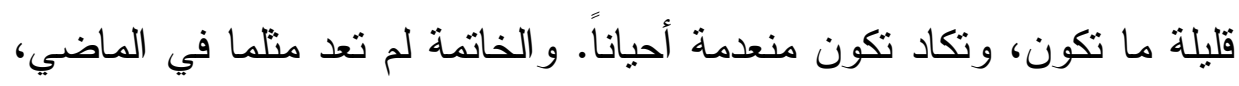

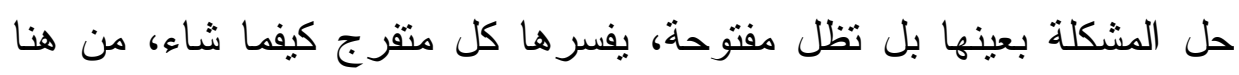

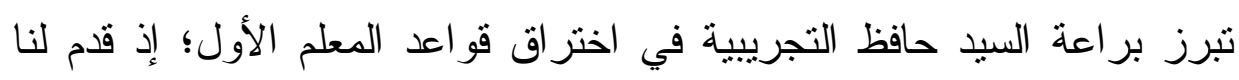

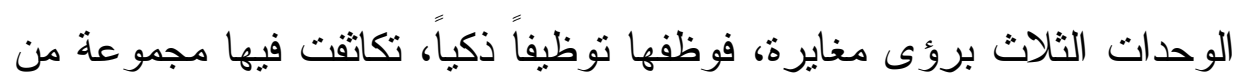

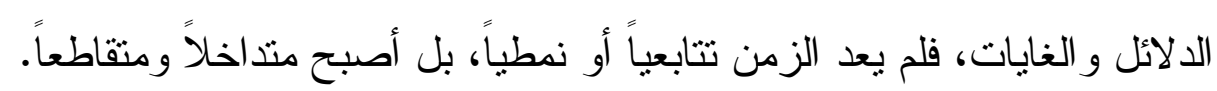

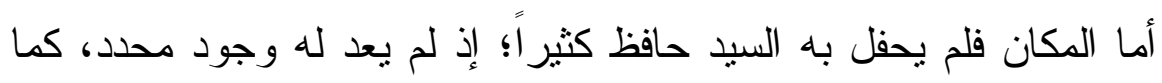

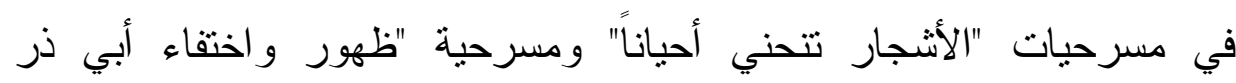

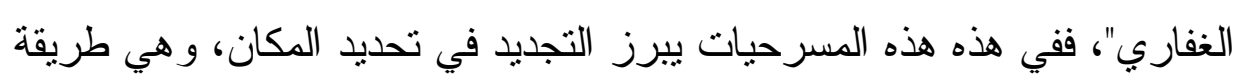

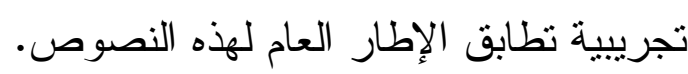

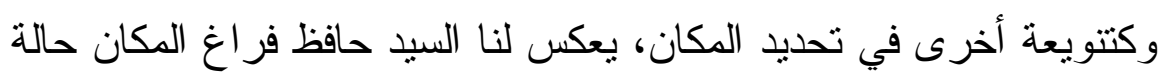

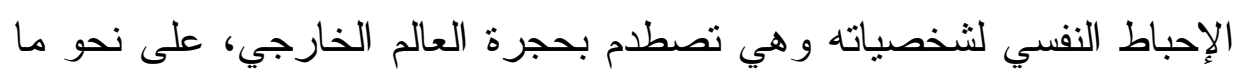

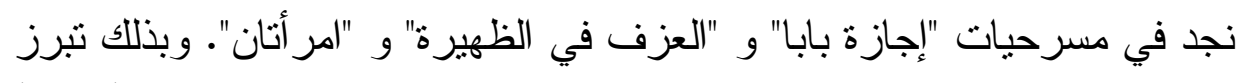

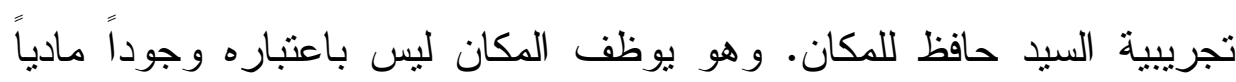
فحسب، بل باعتباره معادلاً إنسانياً"(r).

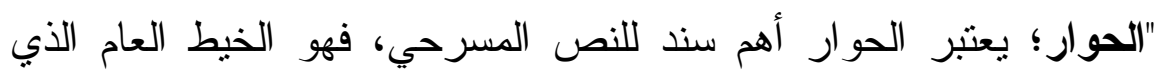
يثد كل الأجزاء، وتكمن قيمته في هذا النسيج لكونه يتيح التعريف بعلاقة الهن

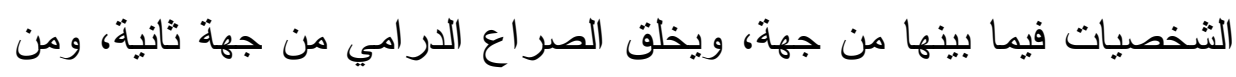

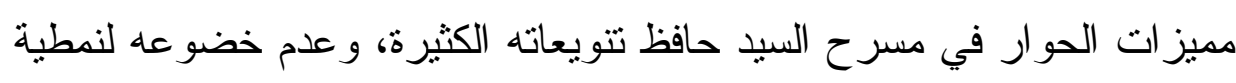

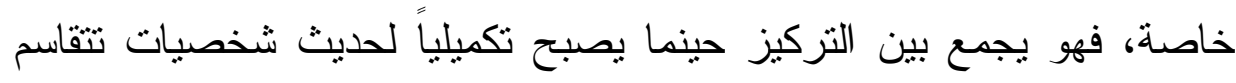
فيه النفوس التصور، وهذا ما نجده ينكرر باستمرار في مجموعة: "الأشجار 
تتحني أحيانا"، فالثخصيات يجمعها مصير واحد، يتميز بطابع انزز امي، وقد

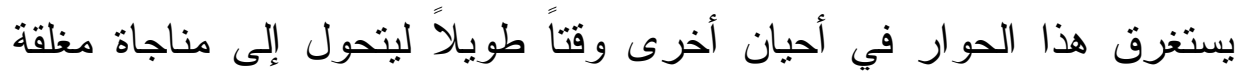

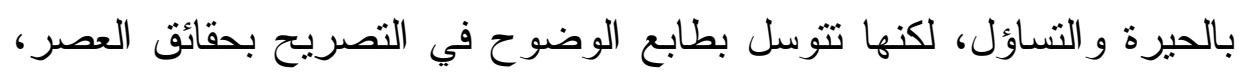

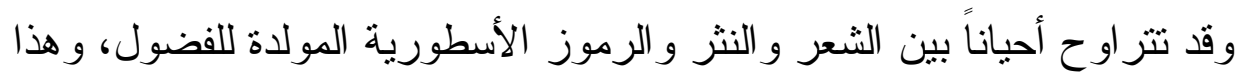

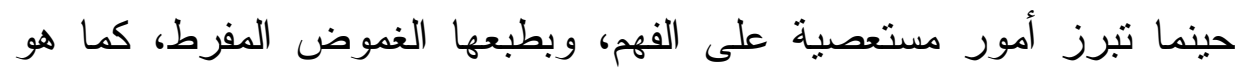
الحال في مسرحيتي "الأشجار تتحني أحياناً" و "معزوفة للعدل الغائب".

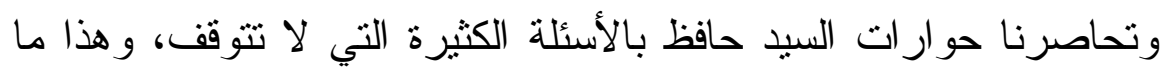

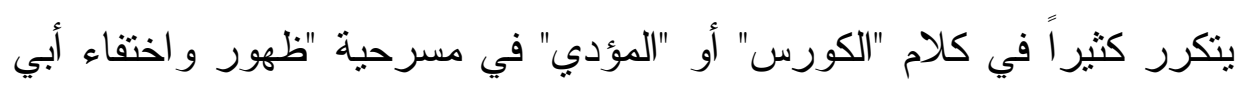

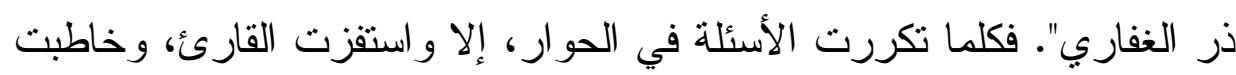

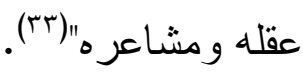

بالإضافة إلى ذلك، فإن الحوار لم يُغيب تناقضات اللو اقع وقضايا الإنسان

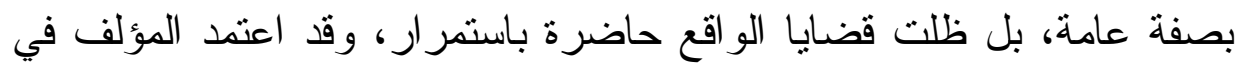

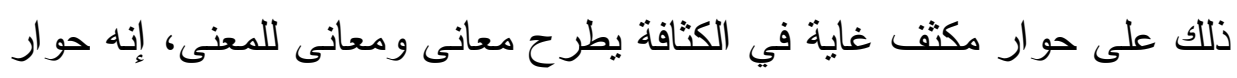
عبثي وفلسفي ساخر وجودي وكوني، فهو حوار يخفي الكثير من المعاني،

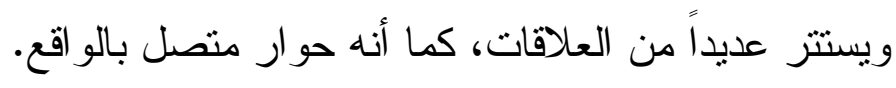

كما ترد هذه الحوارات على شكل مونولوجات تجسد تلك الحيرة الوجودية،

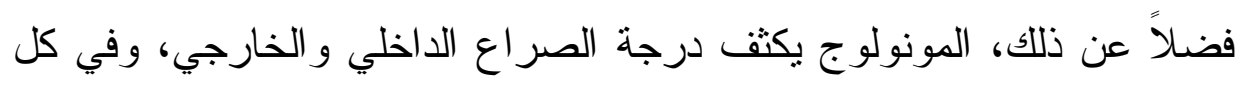

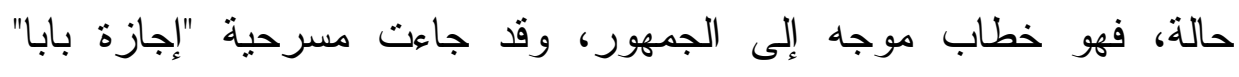

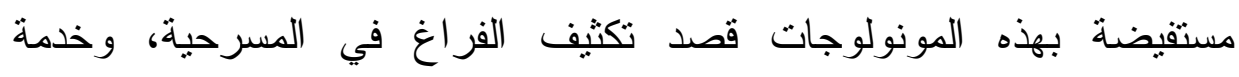
موضو عها الرئيسي. و لا تغفل هذه الحوارات علاقة المتلقي؛ إذ نجدها تتخطى هذه العلاقة

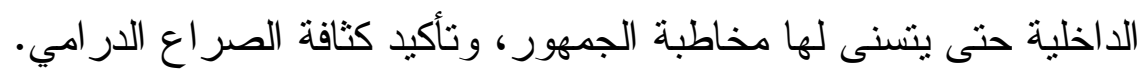




\section{د ـ ـ شيماء فتحي عبدالصادق}

الشخصيات؛ تتميز شخصيات السيد حافظ بتعددها وتتوعها وبعدها عن النمطية مما يبعدها عن الإطار التقليدي، ويقربها من الفعل الحركي النابض، وهي سمة تتسجم مع كل أجواء الحياة التي تعيش فيها، ووفق ذلك فهي التهائ

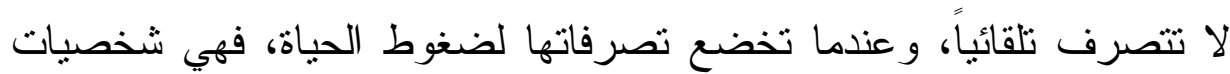
تتحرك على إيقاع الظروف الاجتماعية والسياسية المحيطة بها، وصراعاتها

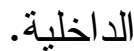

ومن سمات التتويع في مسرح السيد حافظ، التكثيف الكبير لعدد من

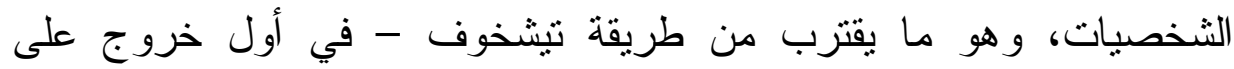

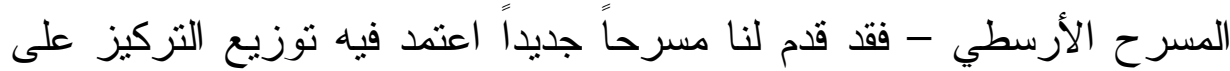
عدد كبير من الثخصيات، متجنباً الأنماط الثخصية المسرحية السائدة.

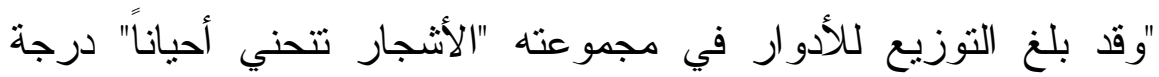

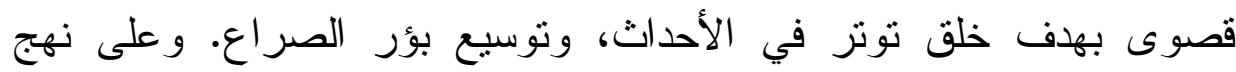

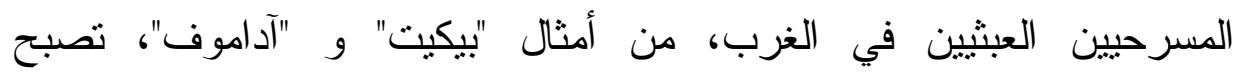
الثخصيات أحياناً غير محدة، بلا هوية، ولا جنس، حيث لا تقدم لنا

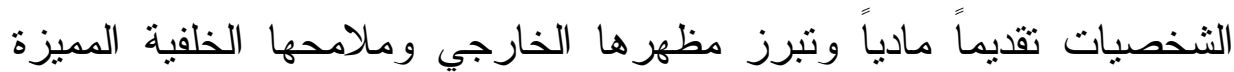
ووضعيتها الاجتماعية وما إلى ذلك، و هذا ما سلكه المؤلف في كثير من أعماله،

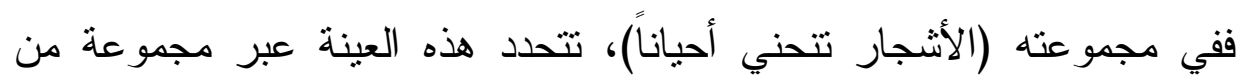

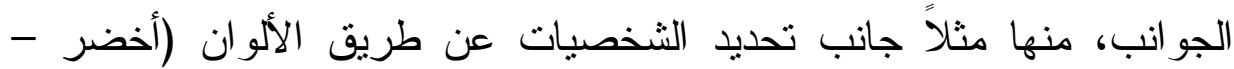

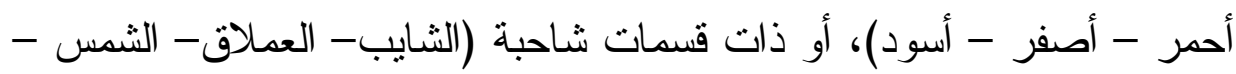
الأسود - الأصفر - القصير ..)، وبهذا تبتعد عن نمط الثخصيات في المسرح

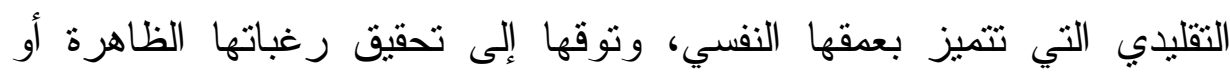

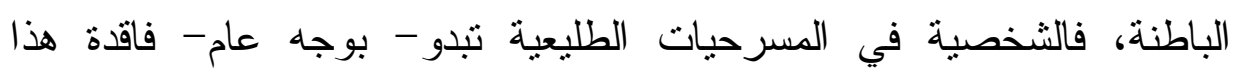
الددى، خالية من تلك الرغبات، تتصرف وفق ضرب من العفوية. 
هذا عن التكوين الخارجي للشخصية، أما عن طوان ابعها الداخلية ومواقفها

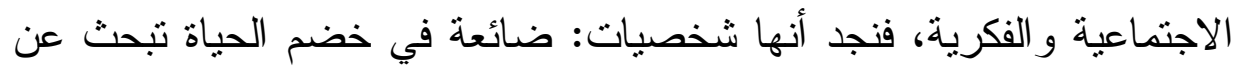

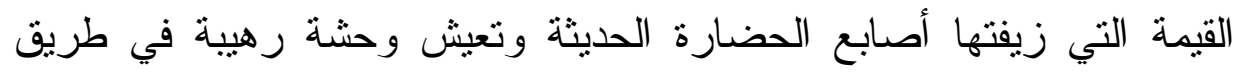

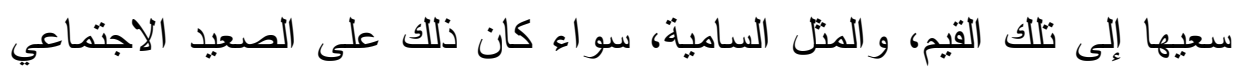
الإنساني، أم الأصعدة الأخرى كالدين و السياسة و الأخلاق"(كُ"). ومما يميز شخصيات مسرحيات السيد حافظ عامة، أن البطل يظل دائل الأماً يصار ع دون أن ينال من أعدائه، وحتى حين يحاول أن يجهز بكلامه لا تتردد

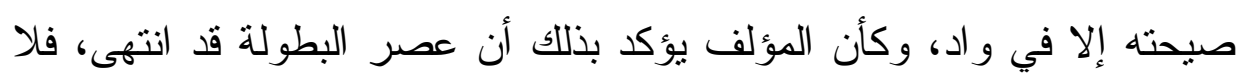
أهمية للتر اجيديا التي تحاول أن تجمع الحقائق عن أخطائنا شعورياً كأبطال.

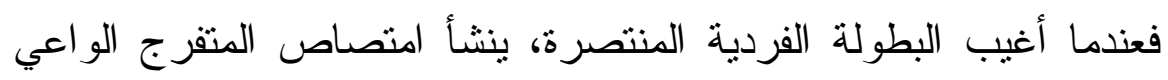

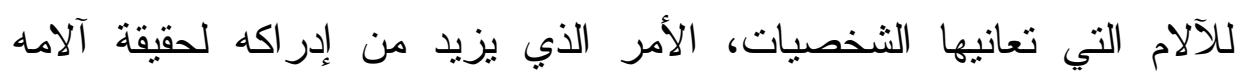

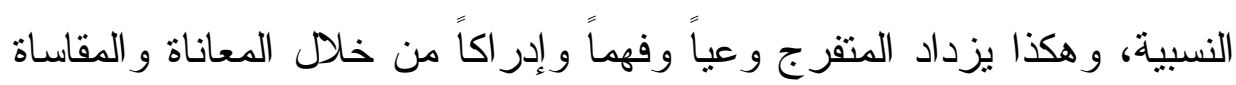
و الآلام.

ومن سمات التجريب للبطل التزاثي أو التاريخي في مسرح السيد حافظ،

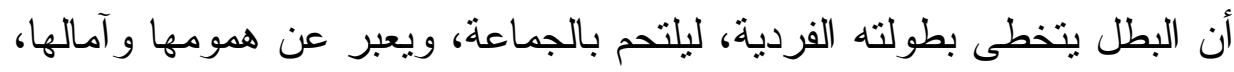

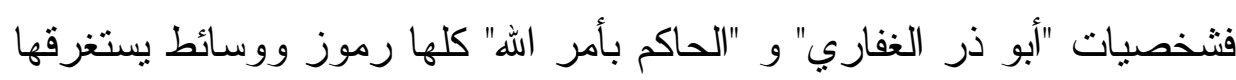
البحث عن وجود زمكاني في خريطة هذا العصر، وهذا لفا الأمر ينطبق أيضاً على "ابن بسبوسة" باعتباره لسان حال هذه الأمة أو شاهداً عليها.

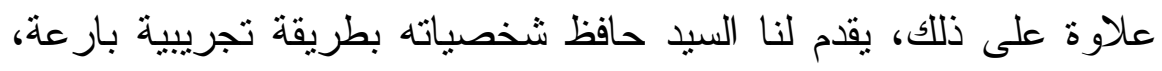

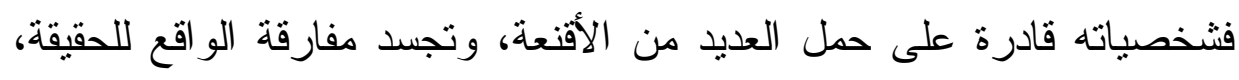

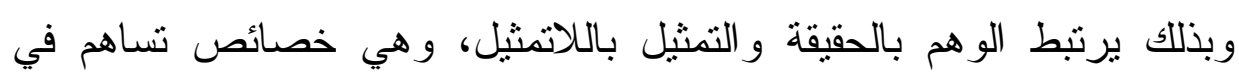
تعميق وعي الجمهور بما يجري أمامه. 


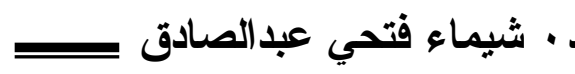

و لإعطاء دينامية جديدة لمفهوم "الكورس" أو "المؤدي"، يحور السيد حافظ

وظيفتهما برؤية مختلفة عن استعمالها عند المسرحبين اليونانبين، حيث كانت الجوقة عندهم مجرد وسيط محايد، تقوم بتفسير أقو ال الممنلين، و التعليق على الأحداث الجارية، أمام المشاهد دون أن ترجح كفة طرف على الآخر. 


\section{هو امش البحث}

(') (علوش) سعيد: معجم المصطلحات الأدبية المعاصرة، دار الكتب اللبنانى، الطبعة

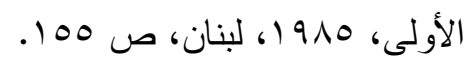

(r) (الجزار ) محمد فكرى: العنوان وسميوطيقيا الاتصال الأدبي، الهيئة المصرية العامة

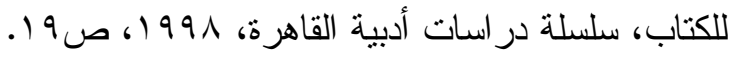

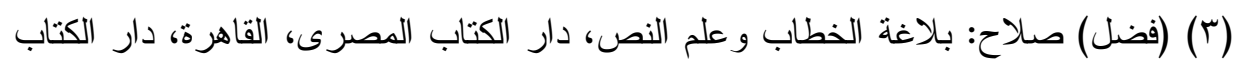

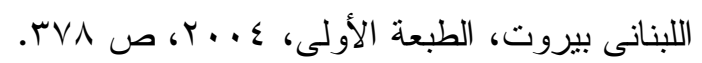

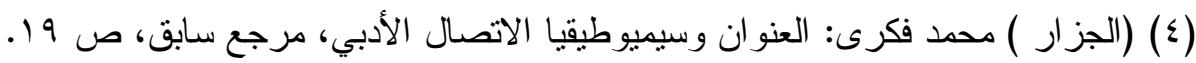

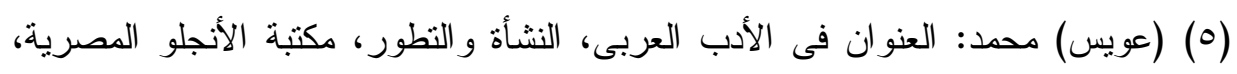

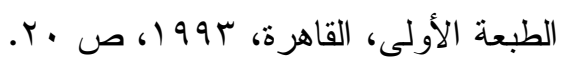

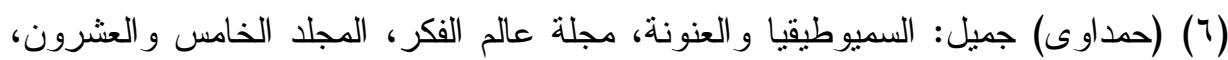

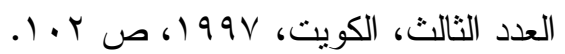

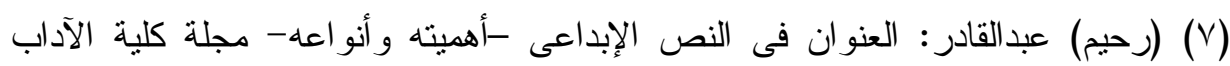

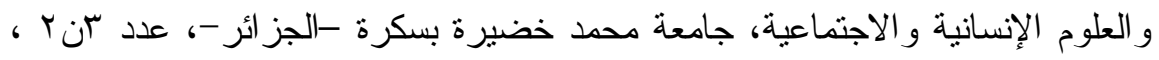

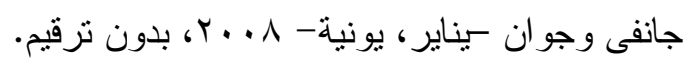

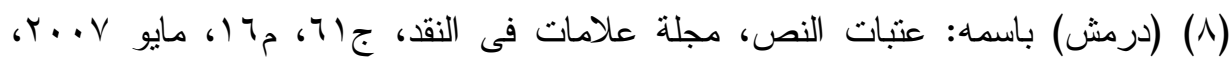
ص. ص.

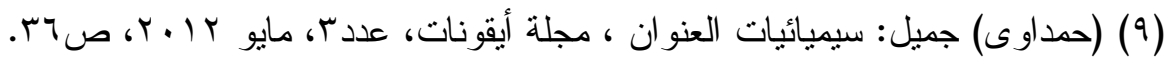

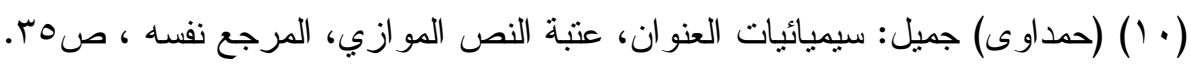

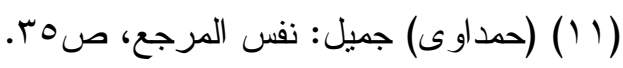

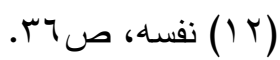

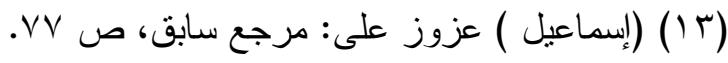

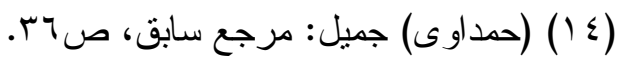

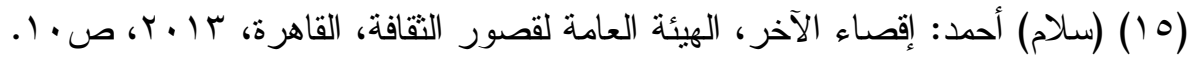

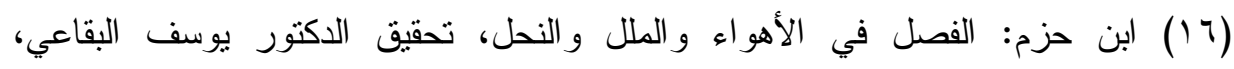

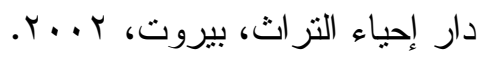




\section{دـ ـ شيماء فتحي عبدالصادق}

( lV) (عبدالحميد) شاكر: الأسس النفسية للإبداع الأدبي في القصة القصيرة، الهيئة العامة

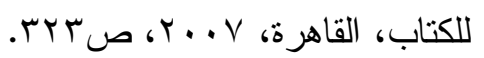

(11) (قاسم) محمود: ملامح البطل في مسرح السيد حافظ، من كتاب في مسرح السيد حافظ،

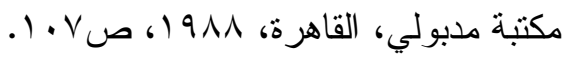

(9 (1) (برشيد ) عبدالكريم: مسرح السيد حافظ بين التجريب و التأسيس، مجلة أدب ونقد،

$$
\begin{aligned}
& \text { سبتمبر } 910 \text { 1، ص } 910 .
\end{aligned}
$$

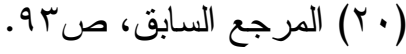

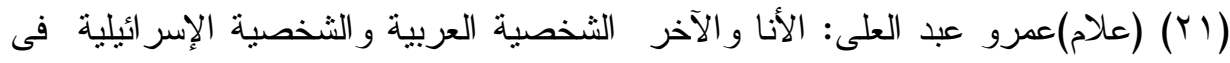

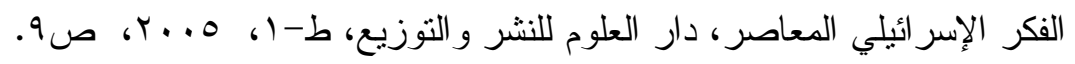

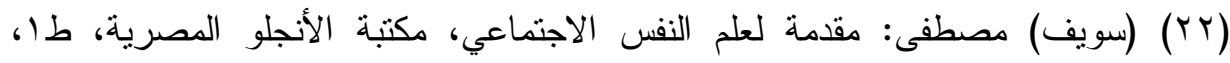

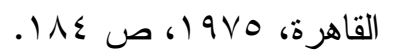

(Yr) (زكريا) حانم حافط: الأنا - الاخر فى خطاب مسرح المهمشين فى الولايات المتحدة

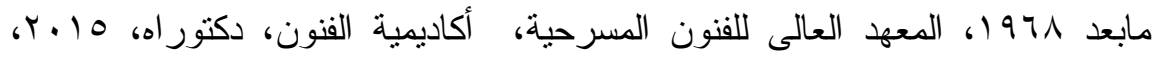

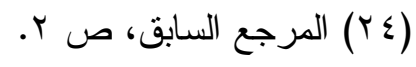

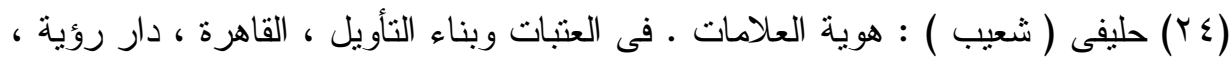

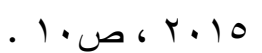

(ف0) (فوكو) ميشال: المعرفة و السلطة، تزجمة عبد العزيز العيادى، المؤسسة الجامعية

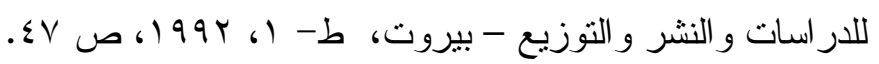

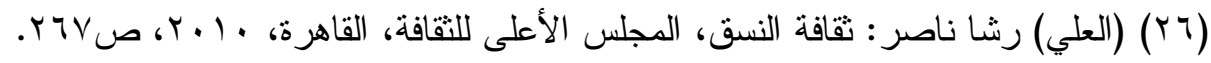
(العسكري) أبو هلال: الفروق اللغوية، تحقيق: حسام الدين القدسي، دار الكتب العلمية، (YV)

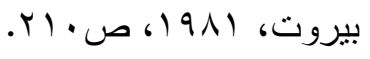

(ابن عوف) عبدالرحمن: قر اءة في مسرحية ظهور واختفاء أبى ذر الغفاري، من (Y)

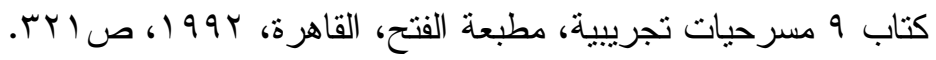

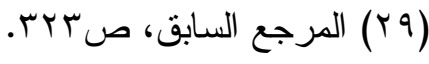

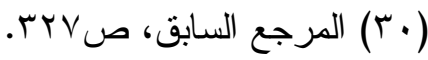


(الب) (العشري ) أحمد: مسرح السيد حافظ بين التجريب و الالتزام وهموم الإنسان، در اسة

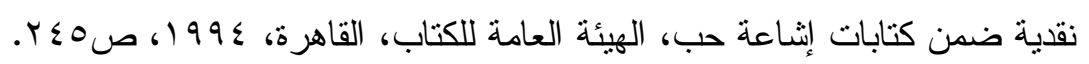

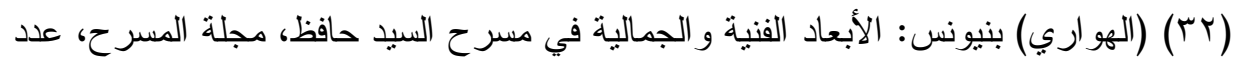

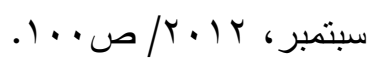

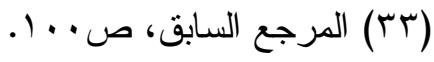

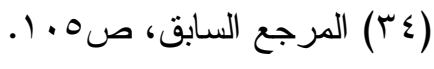




\section{د · شيماء فتحي عبدالصادق عـ}

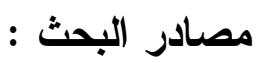

1- السيد حافظ : مسرحية (حبييتى أنا مسافر و القطار أنت و الرحلة الإنسان) ،

مطابع الثقافة ، الإسكندرية ، $19 \vee 9$

r- السيد حافظ : مسرحية (هم كما هم ولكن ليس هم الزعاليك) ، الكويت ، .191.

r- السيد حافظ : مسرحية (ظهور و اختفاء أبى ذر الغفارى) ، 191 . . . ع- السيد حافظ : مسرحية (الطبول الخرساء فى الأودية الزرقاء) ، مكتبة

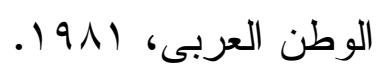

ه- السيد حافظ : مسرحية (حبينى أمبرة السينماء)، مكتبة الوطن العربى، . $19 \wedge \mathrm{r}$

7- السيد حافظ : مسرحية (حكاية مدينة الزعغران) ، قطاع الأداب، المركز

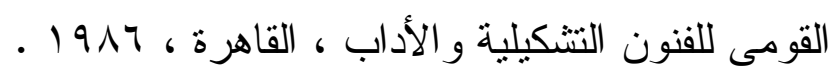

V- السيد حافظ : مسرحية (آرجال فى معتقل - ب شمال حيفا)، مركز الوطن

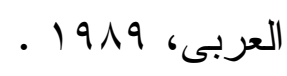

1- السيد حافظ : مسرحية (كبرياء التفاهة فى بلاد اللامعنى)، القاهرة، 199 1. 